\title{
Los Derechos Económicos Sociales y Culturales (DESC), De dónde venimos y hacia dónde vamos.
}

José Luis Zerillo abog., Universidad Nacional de Mar del Plata

"Perded toda esperanza

vosotros los que entráis aqui"

Dante Alighieri. "La divina comedia"

"Persistir en la ilusión geométrica de la

neutralidad de las formas jurídicas

puede ser una manera de contribuir

a la violencia social que las mismas

ejercen."

Andrés García Inda 


\section{INDICE}

Prefacio.

Introducción.

I.- Marco Teórico.

I. 1 Conceptos y definiciones.

I. 2 Relativa Autonomía del Campo Jurídico.

I. 3 Específicamente nos abocamos a los Desc.

II.- Hay derechos y son humanos.

II.1 Francia Monárquica. Sistema económico y social.

II.2 Límites al poder del soberano, libertad de tránsito, libertad económica: Libertad.

II. 3 Derechos ¿Cuáles derechos?

III.- El derecho construyendo derecho ( o paradojas de la vida y el destino)

III. 1 El Derecho.

III. 2 Los Derechos.

III. 3 Cláusulas Operativas y Programáticas.

IV.- Génesis de los Derechos Económicos, Sociales y Culturales.

IV. 1 Y aparece el Comunismo.

IV. 2 Como derechos sí.

V.- Estado Actual.

V. 1 ¿Son derechos o no lo son?

V. 2 Los derechos sociales en tanto derechos.

V. 3 A modo de referencia. Qué dice el Sistema Internacional de Derechos Humanos sobre los Desc.

VI.- Observación del fenómeno descripto

VI. 1 Relaciones de fuerza. Un caso

VI. 2 El legislador y la ley.

VI. 3 Los sistemas antagónicos de acceso a la jubilación VII.- Conclusiones.

VII. 1 De la lucha política a la lucha por el derecho.

VII. 2 Génesis y exigibilidad. 


\section{Prefacio}

Resulta necesario aclarar que el tema elegido para ser desarrollado no surge por generación espontánea. No estábamos un día viendo perderse un barco en el horizonte y dedujimos que la tierra era redonda, ni se nos cayó una manzana en la cabeza para formular las leyes universales que explican los movimientos de los cuerpos gravitatorios.

Lo cierto es que como todo avance en el conocimiento, nuestra propia historia y nuestra dedicación al campo de análisis en estudio, fueron motivos fundantes del problema de investigación planteada.

En tal sentido la labor desarrollada en el Grupo de Investigación "Convención Americana de Derechos Humanos" dirigido por el Dr. Juan Carlos Wlasic, ha cumplido un rol preponderante.

Este grupo de investigación en el transcurso de los años 2008-2009, desarrolló un proyecto denominado "Efectividad y exigibilidad de los Derechos Económicos, Sociales y Culturales. Fundamentación jurídico constitucional. Límites estructurales a su implementación" (Código 15-C079 UNMDP).

En el transcurso del mismo se sistematizó bibliografía y jurisprudencia sobre el tema, lo que permitió precisar las concepciones teóricas subyacentes, se efectuaron precisiones metodológicas para el análisis de discursos y de casos que permitieran ingresar al conocimiento de los límites estructurales existentes, y se abordaron algunas de las cuestiones vinculadas con tales límites como los problemas de interpretación normativa y la pobreza.

A partir de ello, el grupo se propuso profundizar las conclusiones inicialmente arribadas, pero abocándonos al estudio de un derecho económico y social primario, como es el derecho a una alimentación adecuada.

En un segundo proyecto, desarrollado entre 2010 y 2011 denominado “ Derecho a una alimentación adecuada: autonomía, operatividad, exigibilidad" (Código 15-C094 UNMDP) nos abocamos a sistematizar la jurisprudencia nacional e interamericana y el desarrollo de la temática en el derecho internacional, particularmente a partir de los aportes de la FAO, y a su análisis desde una perspectiva crítica, retomando y reelaborando aportes discursivos críticos desplegados inicialmente en nuestro primer proyecto. 
Actualmente, en una tercera etapa de la labor investigativa propuesta y con el fin de ahondar en esta línea de trabajo, nos hemos propuesto, por una parte completar el abordaje del derecho a una alimentación adecuada, asociándolo a la implementación de programas sociales destinados a su cobertura y con ello verificar la extensión y los límites de efectividad del referido derecho, y por la otra ingresar en el análisis del derecho a la vivienda digna. Todo ello lo llevamos a cabo mediante el proyecto denominado "Derecho a la Vivienda Digna: Análisis Crítico de su Tratamiento Constitucional. Legislativo, Doctrinario y Jurisprudencial. Derecho a una Alimentación Adecuada: Análisis Crítico de su realización a través de los Planes Sociales Vigentes en la Argentina”.

Va entonces esta primera aclaración, que explica la introducción a la investigación de la temática que nos convoca y que hoy nos invita a explicarnos la importancia en la génesis de los Derechos Económicos, Sociales y Culturales para comprender su actual estado de exigibilidad y vigencia. 


\section{Introducción}

Queda claro por la formación académica, la dirección elegida para la tesis y el plan de trabajo propuesto, que la presente tesis no pretende ser considerada, ni dedicar su elaboración a un análisis historiográfico de la temática analizada.

Es objetivo primordial de la presente, explicar las causas y orígenes del actual estado de exigibilidad y justiciabilidad de los Derechos Económicos Sociales y Culturales (DESC) y para ello resulta imprescindible efectuar un análisis de las condiciones económicas, sociales y culturales al momento en que los mismos fueron creados en el lenguaje de los derechos.

Para la realización de dicha tarea, se utiliza como marco teórico el relativo a la «autonomía» del campo del derecho - es decir, en tanto el interés principal de ese campo se liga con el interés principal en otros, tales como el del poder del estado, intereses económicos, etc. — todo ello, desde la óptica de Pierre Bourdieu.

Así también, se analizarán los «sentidos», la «imposición» de sentidos y la manipulación de estos, desde el concepto de «violencia simbólica». Se pretende de esta forma ingresar en el análisis de los modos de pensamiento y las prácticas que permiten a grupos de agentes ocupar una posición «instituyente» sobre los DESC en el campo del derecho. Para lo cual, se hará uso del concepto de «habitus» donde se reflejan esos pensamientos, representaciones y prácticas.

Mediante el marco teórico empleado, se analizará críticamente la relativa autonomía del campo del derecho en el análisis de los DESC.

Es dable considerar que contra todas las formas de monismo metodológico, Bourdieu invita a utilizar la primacía de relaciones, apartándonos de la percepción de la realidad social mediante el sentido común, que nos impide captar la lógica del entretejido social; para el autor elegido, la sustancia de la realidad social yace en las relaciones.

"Hay acción, e historia, y conservación o transformación de estructuras solamente porque hay agentes, pero agentes que son actuantes y eficaces solamente porque no se reducen a lo que comúnmente se coloca bajo la noción de individuo, y que, 
como organismos socializados, están dotados de un conjunto de disposiciones que implican tanto la propensión como la habilidad para entrar en un juego y jugarlo"1

Así, teniendo como referencia la metodología propuesta por Bourdieu se procurará la recolección de la información necesaria, que en nuestro caso se centra exclusivamente en material bibliográfico por medio del cual:

a) Se revisará la historia, en lo que atañe al campo del derecho, desde la óptica de su relativa autonomía.

b) Se relacionará el desarrollo capitalista con la aparición de los DESC.

c) Análisis del "caso" elegido, y representativo de los intereses en juego

d) Se analizará dicha información desde el marco teórico seleccionado

Ahora bien, la utilización de dicho marco permitirá adentrarse en la explicación de los motivos, de por qué el actual estado de vigencia de los DESC se diferencia sustancialmente con el ostentado por los Derechos Civiles y Políticos. Y para ello, resulta necesario también poder analizar el contexto en que dichos derechos emergieron, se positivizaron y comenzaron a ser pilares fundamentales de las nuevas Constituciones de los Estados modernos.

Por todo ello, para explicar la situación actual y así explicar el presente, los limites y los defectos -podríamos decir “ congénitos"- en el nacimiento y constitución de los DESC, es que interpelamos a la historia, analizamos críticamente el contexto y motivaciones en las cuales se expandieron ambas categorías de derecho, las comparamos, marcamos sus diferencias, y la persecución de objetivos distintos, y con ello, nos acercamos a la explicación de la situación actual tal como fuera propuesto.

Por ello, si bien se desarrollará un análisis de los hechos y circunstancias en las cuales se desenvuelve la Revolución Francesa a fines del siglo XVIII y la Revolución Rusa a comienzos del Siglo XX, tales referencias, solo lo son al efecto de poder enmarcar históricamente los acontecimientos que ocurrían al momento de la creación de los derechos

${ }^{1}$ Bourdieu Pierre. Una invitación a la sociología reflexiva p 48 
humanos, en una y otra, oportunidad. De ahí que no nos explayemos en bibliografía, citas y referencias mas allá de las absolutamente necesarias para justificar el objeto de la presente.

En tal sentido se torna necesario hacer una aclaración previa. No ha sido considerado con trascendencia determinante para el desarrollo de los objetivos propuestos y la fundamentación de la hipótesis planteada, sin perjuicio de efectuar algunas menciones, el contexto en el cual se desarrolló y posteriormente obtuvo su promulgación la Constitución de los EE.UU.

En primer lugar porque la Constitución promulgada en 1787 no contaba con capítulos dedicados al reconocimiento de derechos de los habitantes, ya que primordialmente tenía como clara finalidad, obtener la independencia gubernativa del Reino de la Gran Bretaña y establecer un gobierno basado en el principio de la división de poderes. Por ello entendemos que dicha declaración de derecho, que fue promulgada a fines del 1791, recibió también una clara impronta generada por los hechos acaecidos en la Revolución Francesa y su Declaración de Derechos del Hombre y del Ciudadano.

Así, le otorgamos a la Declaración de 1789 un rol preponderante a partir de su dictado.

"Como consecuencia, el uso del lenguaje de los derechos aumentó espectacularmente a partir de 1789. La prueba de este incremento se encuentra fácilmente en el número de títulos en ingles que incluían la palabra rights: en la última década del siglo XVIII (418) se multiplicó por cuatro como mínimo respecto a la de 1780 (95) o cualquier otra década anterior del siglo XVIII. Algo parecido sucedió en el caso del holandés: Rechten van den mensch apareció por primera vez en 1791 con la traducción de Paine, y luego hubo muchos otros ejemplos en los últimos años del siglo XVII. La siguió poco después Rechten des Menschen en las tierras de habla alemana. De forma un tanto irónica, pues, la polémica entre autores en lengua inglesa llevó los derechos del hombre franceses a un público internacional. El impacto fue mayor que en 1776 porque los franceses tenían una monarquía como la de la mayoría de las demás naciones europeas y además, nunca abandonaron el lenguaje del universalismo. Los escritos inspirados por la Revolución Francesa también avivaron el debate sobre los derechos en Norteamérica: los jeffersonianos invocaban constantemente los 
derechos del hombre mientras que los federalistas rechazaban el lenguaje asociado al exceso democrático o a las amenazas a la autoridad establecida. Estas disputas contribuyeron a diseminar el lenguaje de los derechos humanos por todo el mundo occidental" 2 .

Circunstancias que, atento a la autolimitación impuesta y que se explicaran al comienzo de la introducción, ameritan poder considerar que las circunstancias explicitadas en el marco de la Revolución Francesa resultan por sí suficientemente esclarecedoras de las posiciones asumidas.

La base propuesta nos permite entonces ingresar desde un posicionamiento crítico al rol del derecho en nuestras sociedades modernas, sin perder de vista el objetivo propuesto.

Para ello nos valemos de una paradoja: el derecho que resulta ser el mejor legitimador de la violencia y el poder, es a su vez, el instrumento implementado para reconocer jurídicamente el acceso a las necesidades y reclamaciones de los habitantes de un estado.

Así, el derecho reconoce a los derechos.

Hablamos de Estado de Derecho, asimilando el mismo con peligrosa ligereza, a un estado democrático, olvidando que tanto el genocidio Nazi, como el terrorismo de estado en nuestro país (por mencionar solo algunos) se valieron de instrumentos jurídicos que legitimaban su accionar.

El derecho, tal cual ha sido reconocido y legitimado a lo largo de los años, no resulta garante per se de estados democráticos.

Si se pretende relacionar al derecho con un estado que garantice la libertad, la igualdad, el respeto de las minorías, la diversidad cultural, todo ello en el marco de una sociedad justa y equitativa, se deberá hablar entonces de un Estado de Derechos, regido por la protección y vigencia de los derechos, y no por normas jurídicas sin más.

El raconto histórico y la puesta en crisis del "derecho" que se efectuara en este trabajo, permitió adentrarse en la génesis de los DESC y en cómo la lucha por el cambio de un sistema económico, social, cultural y político, fue trasmutada al lenguaje de los

\footnotetext{
${ }^{2}$ Lynn Hunt, La Invención de los Derechos Humanos, Tiempo de Memoria Tus Quets Editories, 2010, pag. 138
} 
derechos. Lenguaje que mantiene su forma, pero modifica el fondo, al crear una nueva subcategoría de derechos que no existían hasta el presente, mediante el desarrollo de las llamadas cláusulas operativas y programáticas.

Se verá así cómo la creación de una nueva forma de interpretación de los derechos (en términos nietzscheanos), fue funcional a un sistema que pretendía canalizar las pretensiones comunitarias mediante el derecho, pero sin permitir otorgarles un mismo plano de exigibilidad y vigencia, tal cual se encontraba legislado hasta el presente.

El análisis crítico del surgimiento de los DESC en el lenguaje de los derechos, obliga a profundizar las nociones filosóficas- jurídicas, principalmente desarrolladas por el derecho anglosajón, entre los cuales Robert Nozick es uno de sus exponentes más autorizado, quienes niegan la existencia de los DESC desde una postura liberal conservadora con una fuerte impronta del derecho privado.

Resulta necesario abordar la discusión de si los DESC son derechos o no lo son, para poder así adentrarnos en las conclusiones arribadas.

Así, se desarrollarán las posiciones en uno y otro sentido, quienes consideran que no lo son y quienes analizándolo como derechos, plantean su actual estado de discusión de la cuestión en cuanto a su exigibilidad y vigencia.

Previo a arribar a las conclusiones de la presente tesis, se desarrollará un somero análisis que de forma comparativa permita visualizar el desarrollo de los derechos a la vivienda, salud y alimentación como muestra representativa del estado de la cuestión en el sistema internacional de los derechos humanos, mediante el análisis de las Observaciones Generales dictadas por el comité de Derechos Humanos de las Naciones Unidas, con algunas breves referencias a los fallos de la Corte Suprema de Justicia de la Nación en lo que respecta a los mismos.

El paneo realizado sobre los derechos considerados aquí como muestrario del estado de la cuestión de los DESC, nos permite mediante la toma de análisis de un "caso" concreto, que resulte representativo de los intereses en juego, poner al descubierto los porqué de su actual estado de exigibilidad y vigencia. En el presente, dicho caso se centrará en la abrupta modificación del sistema solidario de acceso a la jubilación en la Argentina. 


\section{Capítulo I}

\section{Marco Teórico}

\section{1.- Conceptos y definiciones:}

En este capítulo se presentarán las herramientas teóricas que permitirán, en el marco de la relativa autonomía del campo jurídico - desarrollado por Pierre Bourdieu comprender cuáles son los elementos instituyentes de la génesis de los DESC que explican su estado actual, en lo que respecta a su positivización, exigibilidad y vigencia.

Al adentrarse en el análisis de la sociología que propone Pierre Bourdieu, se observa la construcción de un lenguaje particular, donde se crean nuevos conceptos a partir de términos forjados del griego, del latín y de otros campos científicos, a fin de romper con el lenguaje corriente.

En palabras del autor, significa, que :

“ Las ciencias sociales deben conquistar todo lo que dicen contra las ideas recibidas vehiculizadas el lenguaje corriente, y decir lo que han conquistado en un lenguaje predispuesto a decir algo muy distinto. Destruir los automatismos verbales no significa crear artificialmente una diferencia distinguida que aleje al profano, significa romper con la filosofía social inscripta en el discurso espontáneo" 3

En tal sentido, tal como lo explica en su breve pero intensa obra Patrice Bonnewitz ${ }^{4}$, algunos de los conceptos desarrollados por Bourdieu, son:

$>$ El concepto de capital, históricamente utilizado en la sociología, amplifica su uso al considerar cuatro tipos posibles de capital. El capital económico constituido por diferentes factores de producción. El capital cultural correspondiente al conjunto de las calificaciones intelectuales. El capital social como el conjunto de las relaciones

\footnotetext{
${ }^{3}$ Pierre Bourdieu Cuestiones de Sociologia Madrid, Istmo 2000 pag. 37

4 Patrice Bonnewitz , La Sociologia de Pierre Bourdieu Ed. Nueva Vision , 2003
} 
sociales de las que dispone un individuo o grupo, como trabajo de sociabilidad. El capital simbólico correspondiente al conjunto de los rituales ligados al honor y el reconocimiento.

$>$ Campo, es definido como una red o una configuración de relaciones objetivas entre posiciones. En sociedades muy diferenciadas, el cosmos social está constituido por el conjunto de esos microcosmos sociales relativamente autónomos, espacios de relaciones objetivas que son el ámbito de una lógica y una necesidad específica e irreductibles a las que rigen los otros campos.

$>$ Hábitus, es un sistema de disposiciones duraderas adquirido por el individuo en el transcurso del proceso de socialización, cuyas disposiciones son actitudes, inclinaciones a percibir, sentir, hacer y pensar, interiorizadas por los individuos debido a sus condiciones objetivas de existencia, y que funcionan como principios inconscientes de acción, percepción y reflexión.

$>$ Violencia Simbólica, es la forma de violencia que se ejerce sobre un agente social con su complicidad. El efecto de dominación surge casi siempre en los ajustes entre los determinantes y las categorías de percepción que los constituyen como tales.

$>$ Doxa como el conjunto de las opiniones comunes, creencias establecidas e ideas convencionales, lo que se da por descontado sin discusión, sólo pueden imponerse en todo un grupo social o toda la sociedad al cabo de un proceso de aleccionamiento.

\section{Relativa Autonomía del Campo Jurídico}

Para el análisis propuesto en esta obra, para la comprensión de la confrontación existente entre las distintas visiones sobre la existencia de las normas jurídicas y con ello las distintas percepciones creadas sobre los DESC, resulta necesario, como se dijera previamente, adentrarse en su genealogía, con el convencimiento que a partir del análisis 
del momento histórico en que surgieron, se podrán comprender las relaciones de fuerza que lo componen hasta nuestros días.

"Muchos errores científicos podrían evitarse si cada sociólogo tuviera presente que las estructuras sociales que él o ella estudia en un momento dado son el producto del desarrollo histórico y de las luchas históricas que deben ser analizadas si uno quiere evitar la naturalización de dichas estructuras. Incluso las palabras que empleamos para hablar acerca de las realidades sociales, las etiquetas que utilizamos para clasificar objetos, agentes y sucesos, como los nombres de ocupaciones y de grupos, todas las categorías opuestas que hacemos en la vida cotidiana y en el discurso científico son productos históricos. Durkheim escribió en La evolución del pensamiento pedagógico que " el inconsciente es historia" y esto es especialmente cierto para el caso del inconsciente científico. Por esta razón, creo que la historia social de la ciencia - en la tradición representada en Francia por Gastón Bachelard, Gerorges Canguilhem y Michel Foucalt - debería ser parte imprescindible de la caja de herramientas intelectuales de todo científico social." 5

Comúnmente, al efectuar una sociología del campo jurídico, se consideraba a la ciencia del derecho como una ciencia jurídica a secas, esto es sometiendo la misma al formalismo que afirma la autonomía absoluta de la forma jurídica o al instrumentalismo que concibe el derecho como un reflejo al servicio de los dominantes.

En la primera de ellas, como refiere Bourdieu, se encontraba la Teoría Pura del Derecho de Kelsen:

“La reivindicación de la autonomía absoluta del pensamiento y de la acción jurídicas se afirma en la constitución en teoría de un modo de pensamiento específico totalmente eximido del pensamiento social, y la tentativa de Kelsen de fundar una teoría pura del derecho - no es sino el límite ultra consecuente del esfuerzo de todo el cuerpo de juristas para construir un cuerpo de doctrinas y de reglas totalmente

\footnotetext{
${ }^{5}$ Pierre Bourdieu, "Poder, Derecho y Clases Sociales” Ed. Desclee de Brouwer SA , pag. 75
} 
independiente de sujeciones y presiones sociales y que encuentra en sí mismo su propio fundamento ${ }^{. * 6}$

Por el contrario, en su segunda vertiente, se encuentran quienes ven en el derecho y la jurisprudencia, un reflejo directo de las relaciones de fuerza existentes, donde se expresan las determinaciones económicas y en particular los intereses de los dominantes, o bien lisa y llanamente un instrumento de dominación.

....los marxistas llamados estructuralistas han ignorado paradójicamente la estructura de los sistemas simbólicos y, en particular, la forma específica del discurso jurídico. Y esto porque, al haber reiterado la afirmación ritual de la autonomía relativa de las "ideologias” han omitido plantear la cuestión de los fundamentos sociales de esa autonomía“

Por ello, se propone mediante el uso del presente marco teórico, romper con la ideología de la independencia del derecho y del cuerpo judicial, sin caer por ello en la visión opuesta, otrora citada.

Nos dice Bourdieu entonces:

..... es necesario tener en cuenta lo que las dos visiones antagónicas, internalista y externalista, ignoran en común: esto es, la existencia de un universo social relativamente independiente en relación a las demandas externas en cuyo interior se produce y se ejerce la autoridad jurídica, forma por excelencia de la violencia simbólica legítima cuyo monopolio pertenece al Estado y que puede servirse del ejercicio de la fuerza física. Las prácticas y los discurso jurídicos son, en efecto, el producto del funcionamiento de un campo cuya lógica específica está doblemente determinada: por una parte por las relaciones de fuerza específicas que le confieren su estructura ..... y por otra parte, por la lógica interna de las obras jurídicas que delimitan en cada momento el espacio de lo posible..7

\footnotetext{
6 Pierre Bourdieu, Ob cit. pag. 165

${ }^{7}$ Pierre Bourdieu, Ob cit pag. 167
} 
Así, siendo el campo jurídico el lugar de la concurrencia por el monopolio del derecho, de decir el derecho, el lugar donde se enmarca el enfrentamiento entre los agentes capaces de interpretar el corpus de textos que consagran la visión legítima, recta, del mundo social, no es ni más ni menos que un objeto de luchas. Ello, dado que la lectura del texto jurídico es una manera de apropiarse de la fuerza simbólica que se encuentra dentro.

Es decir, ver el campo jurídico como lugar de relaciones de fuerza, como campo de luchas donde hay intereses en juego, donde los diversos agentes e instituciones ocupan posiciones diferentes según el capital especifico que poseen y elaboran distintas estrategias para defender su capital.

En ese marco, es que se debe comprender que la mayor parte de los procedimientos lingüísticos característicos del lenguaje jurídico concurren efectivamente en la producción de dos efectos, el de neutralización y el efecto de universalización:

"El efecto de neutralización se obtiene mediante un conjunto de rasgos sintácticos tales como el predominio de las construcciones pasivas y de los giros impersonales apropiados para subrayar la impersonalidad de la enunciación normativa y para hacer del emisor un sujeto universal, a la vez imparcial y objetivo. El efecto de universalización se obtiene a través de diferentes procedimientos convergentes: el recurso sistemático al indicativo para enunciar las normas...." 8

\section{2.- Específicamente nos abocamos a los Desc}

A esta altura de los acontecimientos, comprenderá el lector que la construcción de los Desc en el lenguaje de los derechos, no escapa a la relativa autonomía del campo jurídico que plantea Bourdieu y que se expresa indirectamente en gran parte de su obra.

“ La concurrencia por el monopolio del acceso a los recursos jurídicos heredados del pasado contribuyó a profundizar el corte social entre los profanos y los

\footnotetext{
${ }^{8}$ Pierre Bourdieu, Ob cit. 173
} 
profesionales, favoreciendo un trabajo continuo de racionalización apto para aumentar cada vez más la diferencia entre los veredictos armados de derecho y las intuiciones ingenuas de la equidad y para hacer que el sistema de normas jurídicas aparezca a aquellos que lo imponen e incluso, en mayor o menor medida, a aquellos que lo sufren, como totalmente independiente de las relaciones de fuerza que sanciona y consagra. ....Es claro que como muestra particularmente bien la historia del derecho laboral, el corpus jurídico resigna en cada momento un estado de relación de fuerzas y sanciona por tanto las conquistas de los dominados, convertidas así en logros reconocidos ( lo cual tiene por efecto inscribir en su misma estructura una ambigüedad que contribuye sin duda a su eficacia simbólica)...."9

Así, el planteo de la existencia y reconocimiento de un derecho y a su vez el desarrollo del discurso jurídico planteando su inexigibilidad, sólo puede comprenderse en el marco de la polisemia de las fórmulas jurídicas, que permite justificar y argumentar así, lo mismo y lo contrario al mismo tiempo, en las amplias fronteras del derecho.

“ Dada la extraordinaria elasticidad de los textos, que a veces llega hasta la indeterminación o el equívoco, la operación hermenéutica de la declaratio dispone de una inmensa libertad. No es nada extraño que el derecho, instrumento dócil, adaptable, flexible y polimorfo, sea utilizado, en realidad, para contribuir a racionalizar ex post decisiones en las que él no ha tenido ninguna participación. ....Haciendo acceder al estatuto de veredicto una decisión judicial que, sin duda, debe más a las disposiciones éticas de los agentes que a las normas puras del derecho, la labor de racionalización le confiere la eficacia simbólica que ejerce toda acción cuando, desconocida en su arbitrariedad, es reconocida como legítima." 10

Las reclamaciones sociales que peticionaron un cambio en las condiciones de prestación del trabajo, la acumulación de la riqueza y el acceso a beneficios económicos y

\footnotetext{
${ }^{9}$ Pierre Bourdieu, Ob cit 170

10 Pierre Bourdieu, Ob cit 185
} 
sociales, fue gratamente recibida por el campo jurídico a sabiendas que no escaparía a una de las leyes fundamentales del mismo.

“ La entrada en el universo jurídico va acompañada de una redefinición completa de la experiencia ordinaria y de la situación misma que es el objeto en litigio, debido a que dicha entrada implica la aceptación tácita de la ley fundamental del campo jurídico, tautología constitutiva que pretende que los conflictos sólo puedan ser regulados jurídicamente, esto es, según las reglas y las convenciones del campo jurídico. La constitución del campo jurídico es un principio de constitución de la realidad (lo cual es válido para todo campo). Entrar en el juego, aceptar jugar el juego, de remitirse al derecho para solucionar el conflicto, es aceptar tácitamente la adopción de un modo de expresión y de discusión que implica la renuncia a la violencia física y a las formas elementales de violencia simbólica, como la injuria" 11

Como se verá más adelante, la aceptación de dicha regla del campo jurídico y la solución del conflicto solamente mediante la vía allí prevista, en los términos en que los Desc. fueron reconocidos, determinará fuertemente el estado de exigibilidad y vigencia de los mismos.

Se ha sostenido entonces que la eficacia de la violencia simbólica, como parte de la fuerza del derecho, deviene en que sólo se puede ejercer con la complicidad de los que la sufren, tanto más segura cuanto más inconsciente es, o sea, cuanto más sutilmente arrebatada fue.

Así, nos enseña Bourdieu que el ingreso al derecho de las reclamaciones políticas, implica también un reconocimiento a la creencia de un orden jurídico y sus prácticas.

“Forma por excelencia del discurso legítimo, el derecho, no puede ejercer su eficacia específica más que en la medida en que obtenga reconocimiento, es decir, en la medida en que permanezca desconocida la proporción más o menos amplia de arbitrariedad que está en el principio de su funcionamiento. La

\footnotetext{
11 Pierre Bourdieu, Ob cit 191
} 
creencia tácitamente otorgada al orden jurídico debe ser reproducida sin cesar; y una de las funciones del trabajo propiamente jurídico de codificación de las representaciones y de las prácticas éticas es contribuir a fundar la adhesión de los profanos a los fundamentos mismos de la ideología profesional del cuerpo de juristas, a saber, la creencia en la neutralidad y la autonomía del derecho y los juristas" (Alain Bancaud e Yves Dezalay demuestran cómo hasta los juristas críticos más heréticos, que recurren a la sociología o al marxismo para hacer avanzar los derechos de los detentadores de formas dominadas de la competencia jurídica, como el derecho laboral, continúan reivindicando el monopolio de la" ciencia jurídica").$^{12}$

\section{Capítulo II}

\section{Hay derechos y son humanos}

Fue expuesto con claridad y reafirmado desde el inicio, que el objeto de investigación de esta Tesis no pretende abarcar todas las circunstancias y causas que motivaron la aparición de los Derechos Humanos en el mundo moderno tal cual hoy los conocemos, sino poder comprender el contexto histórico en el cual los mismos surgieron, para de esta forma contextualizar y comprender las circunstancia en que hicieron su aparición los Derechos Económicos, Sociales y Culturales y con ello analizar su actualidad, exigibilidad y vigencia.

Es cierto que escudriñar el origen de los DD.HH, remonta a antecedentes medievales que tuvieron una importancia mayúscula en la discusión sobre el poder y su ejercicio, en el proceso de construcción de los Derechos Humanos y que claramente enmarcaron la discusión posterior sobre la temática. Así, en forma enunciativa, debemos recordar por lo menos: la aparición en el año 1188 de la Carta Magna Española otorgada por el Rey de León y Galicia, la Carta Magna Inglesa de 1215, como posteriormente también la Petición de Derechos (Petition of Right) de 1628 y la Declaración de Derechos (Bill of Right) de 1689, todos hitos trascendentes que antecedieron a la Revolución Francesa y su posterior Declaración de Derechos del Hombre y del Ciudadano.

\footnotetext{
12 Pierre Bourdieu, Ob cit 210
} 
Pero sin perjuicio de ello, se entiende aquí que la trascendencia de la Revolución Francesa en la aparición de los Derechos Humanos tiene una preponderancia hegemónica que merece una dedicación exclusiva, en el marco del presente trabajo, para explicar el contexto histórico, económico, social y político en que surge la primer Declaración de Derechos Humanos que marca el horizonte por el cual se planteará, de ahora en más, la discusión sobre la existencia de los derechos en el mundo moderno.

El proceso revolucionario vivido entre los años 1789/1793 en la Francia post Luis XVI fue el prolegómeno de un particular contexto social que explica las condiciones en las cuales se crearon los DD.HH, por lo que merece ser detenidamente analizado.

\section{1.- Francia Monárquica. Sistema económico y social.}

Mucho se ha dicho y escrito sobre el absolutismo monárquico en la Francia del siglo XVIII, analizado principalmente desde una óptica de opresión sobre lo que hoy se entienden como derechos y libertades individuales, relacionada a la utilización arbitraria de los sistemas represivos del estado, vinculado a la libertad individual, el sometimiento a tormentos, la directa dependencia del poder judicial del poder administrador, etc. Pero se considera necesario no ahondar sobre situaciones ya analizadas con anterioridad, sino abocarse al contexto económico en que gobernó los últimos años de la Monarquía de Luis XVI, la cual se entiende aquí, resultara determinante para el proceso revolucionario que se iniciara a comienzos de 1789, con el emergente de su Declaración de Derechos del Hombre y del Ciudadano incluida.

Este marco impuesto al análisis del sistema económico imperante en la Francia prerevolucionaria, permite acotar el campo de estudio a las circunstancias más relevantes a ser tenidas en cuenta para comprender el surgimiento de los principios de Liberté, égalité, fraternité; y con posterioridad la confrontación que se generara entre los mismos, a partir de clarificarse los verdaderos objetivos perseguidos por las clases dominantes que participaron en la Revolución Francesa.

La ampliación de los mercados, la expansión rápida del comercio no sólo a nivel nacional, sino internacional, estimulada por los descubrimientos de ultramar, la intensa afluencia de metales preciosos provenientes de América, utilizables como moneda, la 
intensificación de la producción agraria y la declinación de la producción de mera subsistencia, propia del feudalismo - en franca decadencia - unidas a la creencia de que la verdadera riqueza tanto de un país como de un particular, consistía en la acumulación de metales preciosos, determinaron por parte del Estado la implantación de una serie de medidas regulatorias de la economía, facilitadas por el carácter absoluto del poder central, que era el del monarca o el del príncipe. Fue así como se dictaron normas proteccionistas tendientes a limitar las importaciones y se alentaron las exportaciones mediante subsidios; se regularon tanto los salarios como el interés del dinero: se concedieron a la industria privilegios de monopolio; se limitaron las exportaciones de materias primas consideradas indispensables a ella y se impusieron, a la par, severas restricciones generales sobre las actividades industriales y comerciales de los individuos. ${ }^{13}$

Claramente se había optado desde hace décadas por una economía regulada, por un mercado regulado y por profesiones u oficios regulados.

Se procuraba así garantizar la mayor intervención posible del Estado en la economía, a fin de promover la riqueza, el beneficio del conjunto de la sociedad y en definitiva el bienestar general. Con tal objetivo, es que se reforzó el régimen corporativo, se prohibieron las coaliciones y las huelgas, se promulgaron reglamentos sobre las materias primas, los procedimientos de fabricación y la organización del trabajo. Tales medidas, permitieron la construcción de un Estado fuerte, donde la intervención en la economía y el dirigismo económico caracterizarían dichas etapas de gobierno. ${ }^{14}$

El dirigismo económico fue paulatinamente expresado como anteposición al concepto de libertad. Es decir, el cambio del sistema imperante y el "mejoramiento" de las condiciones socio-económicas vendrían, en el imaginario social, de la mano de mayor libertad. Concepto primeramente referido a las cuestiones económicas y que luego de forma amplia, genérica, derramará y se extenderá a todos los ámbitos de participación estatal. Siendo el estado un brazo de la Monarquía absoluta a ser derrocada, la representatividad de estado, absolutismo, monarquía vs. la libertad, permitió generar los consensos públicos para considerar que la libertad de mercado era una forma también de combatir el poder absoluto del soberano.

\footnotetext{
13 Arthur Scheldon y FG. Pennance, Diccionario de Economia, Orbis, Barcelona, 1983, pag. 357

14 Jose Maria Torres, Los Derechos del Hombre, Editorial Universitaria de Buenos Aires 1989, pag68.
} 
Una economía dirigida fue considerada a lo largo de los años como parte de un poder absoluto puesto en crisis. Por lo que una y otra característica retroalimentaba las concepciones libertarias, que se sostuvieron primero en lo económico y rápidamente se ensanchara a los conceptos libertarios en el ámbito, social, político, cultural.

\section{2.- Limites al poder del soberano, libertad de tránsito, libertad económica: Libertad}

El contexto referido fue sin duda uno de los motivos fundantes para empezar a desarrollar en la sociedad francesa de fines del siglo XVIII los conceptos de limitación de los poderes del soberano (concepto desarrollado previamente en el ámbito tributario y que rápidamente se extendiera a las limitaciones en cuanto a las facultades sobre la libertad individual), libertad para comerciar, libertad de contratar, libertad de tránsito. Todas dichas exigencias no dudaron en ampliar el marco de reclamación de derechos, por lo que en donde primero hubo reclamo para garantizar ciertos derechos, rápidamente hubo reclamos para garantizar la ampliación de los márgenes de la libertad. Lo que llevó a poner en discusión el poder del Rey y cuáles eran sus límites, hasta llegar a discutir la misma legitimidad monárquica como forma de gobierno.

Se vislumbra así un contexto económico donde la regulación por parte del Estado limitaba las apetencias de una burguesía cada vez más fortalecida, lo que resultara ser el caldo de cultivo para que germinara la idea de la libertad en todas sus formas de expresión. La idea fundante, el núcleo, el big bang de dicho proceso que desencadenara en la Revolución Francesa, fueron sin duda las exigencias de mayores libertades económicas. Así, incluso se reflejó en los primeros intentos de crear derechos y positivizarlos.:

“En 1768, por ejemplo, el economista francés de perfil reformista Pierre - Samuel du Pont de Nemours realizó su propia definición de los derechos de cada hombre. Su lista incluía la libertad de escoger ocupación, el librecambio, la educación pública y la tributación proporcional."

\footnotetext{
${ }^{15}$ Lynn Hunt, Ob Cit pag. 128
} 
Se buscaba en definitiva mayor libertad económica y restringir el poder discrecional de la Monarquía. Pero ambos objetivos tendían primordialmente a modificar la estructura económica imperante y permitir con ello márgenes de discrecionalidad y liberalidad económica.

El hecho de reconocer en las exigencias de una mayor liberalidad del sistema económico vigente la base del reclamo que deviniera en la posterior construcción de la primera declaración de derechos del mundo, nos permite asumir los motivos e inspiraciones que generaron dicha construcción jurídica. Y el poder descubrir cuáles fueron las primeras razones que motivaron la citada declaración de derechos, nos permite comprender su actual status jurídico, en comparación con los derechos que fueran reconocidos con posterioridad y ante otros contextos históricos y políticos. Esto último es el tema que sin duda ocupará una parte sustancial del presente trabajo.

Pero vayamos por parte.

Decíamos que la gesta de los derechos se inició con un primer reclamo, básico y esencial. Liberalizar el mercado. ¿Y cuál fue la diferencia con los anteriores intentos de limitación de los poderes soberanos referidos al comienzo?. Que ahora la exigencia de dicha liberalidad de mercado venía acompañada de la necesidad de un explosión de los procesos productivos, diferente a los contextos donde emergieron las primeras Cartas Magnas tanto del Siglo XII, como del Siglo XIII, ya que los actuales procesos económicos se encontraban en un proceso de expansión manufacturera y en los albores de una sociedad industrial.

Claramente en el momento de la Revolución Francesa se estaba en los preludios de una sociedad capitalista y la declaración de derechos tenía como finalidad primordial garantizar que dicha sociedad se desarrollara.

La construcción de la norma devino necesaria como forma de garantizar y asegurar la construcción de las bases de una nueva sociedad construida sobre los pilares de lo que hoy entendemos por una economía de mercado.

El derecho como mecanismo de regulación social, de imposición de las clases dominantes, de expresión de la violencia simbólica, fue sin duda el mecanismo necesario e imprescindible para garantizar una institucionalidad que aseguraba los márgenes de protección que requería la nueva realidad impuesta. 
Así, la Declaración de Derechos del Hombre y el Ciudadano fue la instrumentación, la construcción legal, que garantizó para Francia pero, por su trascendencia también para el resto del mundo occidental, las bases sobre las que se asentaría el desarrollo económico de la era industrial.

No podemos soslayar la trascendencia que tuvieron tales conceptos desarrollados en el proceso revolucionario, la elaboración de nuevas instituciones, las concepciones sobre el poder y sobre todo la construcción jurídica de creación de derechos, en los posteriores procesos de Independencia Latinoamericanos, en donde la obligación de comerciar sólo con la corona Española fue sin duda uno de los principales motivos que llevó a que una gran parte de las minorías ilustradas de las Américas abrazaran las causas independentistas.

Todo ello, a su vez, siendo claramente fomentado desde la propia Francia hacia el resto del mundo.

“ En esta perspectiva, la Revolución Francesa aparece como el mito fundador y legitimador de la pretensión de Francia a la universalidad, y, al mismo tiempo, al derecho a la universalización de su cultura nacional. Al tener Francia por cultura nacional una cultura que se pretende universal, los franceses se sienten autorizados (al menos hasta la Segunda Guerra Mundial) a una forma de imperialismo cultural que reviste la apariencia de un proselitismo legítimo de lo universal. Jamás se observa esto tan bien como en sus empresas de colonización: como bien lo demuestra la historia comparada de las estrategias de colonización de los franceses y de los ingleses, la colonización francesa, frecuentemente concebida como misión civilizadora y emancipadora, se caracteriza por una extraordinaria certidumbre de sí, fundada sobre la certidumbre de tener por particularidad la universalidad" 16

Es así que se sostiene que el proceso de la Revolución Francesa, que excede la positivización obtenida mediante la Declaración de Derechos, impregnó sus contenidos mucho más allá de sus fronteras.

${ }^{16}$ Pierre Bourdieu, Intelectuales política y poder Ed. Eudeba 2006, pag. 154 
Era necesario el desarrollo de los conceptos libertarios para garantizar los márgenes necesarios de desregulación de mercado que permitieran el desarrollo comercial de una incipiente sociedad industrial, que requería de nuevas reglas de juego para expandirse.

En tal sentido, adherimos al diagnóstico efectuado por Eric Hobsbawm cuando sostiene:

“ Si la economía del mundo del siglo XIX se formó principalmente bajo la influencia de la Revolución industrial inglesa, su política e ideología se formaron principalmente bajo la influencia de la Revolución francesa. Gran Bretaña proporcionó el modelo para sus ferrocarriles y fábricas y el explosivo económico que hizo estallar las tradicionales estructuras económicas y sociales del mundo no europeo, pero Francia hizo sus revoluciones y les dio sus ideas, hasta el punto de que cualquier cosa tricolor se convirtió en el emblema de todas las nacionalidades nacientes. Entre 1789 y 1917, las políticas europeas ( y las de todo el mundo) lucharon ardorosamente en pro o en contra de los principios de 1789 o los más incendiarios todavía de 1793. Francia proporcionó el vocabulario y los programas de los partidos liberales, radicales y democráticos de la mayor parte del mundo. Francia ofreció el primer gran ejemplo, el concepto y el vocabulario del nacionalismo. Francia proporcionó los códigos legales, el modelo de organización científica y técnica y el sistema métrico decimal a muchísimos países. La ideología del mundo moderno penetró por primera vez en las antiguas civilizaciones, que hasta entonces habían resistido a las ideas europeas, a través de la influencia francesa. Esta fue la obra de la Revolución Francesa." 17

Para que se desarrollara la potencialidad del proceso de la Revolución Industrial, hito del nacimiento de una sociedad capitalista, debimos atravesar la Revolución Francesa y su construcción jurídica que garantizaba las reglas de juego para el posterior desarrollo económico capitalista. Así, el resultado más importante fue, tal vez, el haber abierto la carrera a la energía, a la capacidad de trabajo y por supuesto a la ambición.

${ }^{17}$ Hobsbawm Eric, La Era de la Revolución 1789-1848, Critica , 2010, pag. 61. 
Francia fue a las Ciencias Sociales lo que Inglaterra al aporte técnico de un sistematizado desarrollo de la industrialización de la manufactura.

Pero tal desarrollo sólo fue posible a partir del cambio de época:

“El grandísimo número de los que ahora vegetaban sobre la tierra a la que toda la historia humana les ligaba, pero que, si eran explotados productivamente, resultarían un exceso de población, tenían que ser arrancados de sus raíces y autorizados a trasladarse libremente. Sólo así emigrarían a las ciudades y fábricas en las que sus músculos eran cada vez más necesarios. En otras palabras: los campesinos tenían que perder su tierra a la vez que los demás vínculos. En la mayor parte de Europa esto significa que el complejo de tradiciones relaciones legales y políticas conocidas generalmente por $=$ feudalismo $=$ tenía que abolirse en donde aún no había desaparecido. Puede afirmarse que esto se logró en el período entre 1789 y 1848 - casi siempre como consecuencia directa o indirecta de la Revolución Francesa-. 18

Se necesitaba el marco jurídico de la libertad de trasladarse para poder así nutrir de mano de obra a los incipientes procesos productivos que se desarrollaban en las ciudades florecientes. La propiedad de la tierra tenía que convertirse, transmutarse, en el capital de la fuerza de trabajo. Aparecería así, no sin preverlo en la redacción de las nuevas condiciones, el concepto del trabajador dependiente, del proletariado.

Al capital tierra lo reemplazará el capital mano de obra.

Por todo ello, es posible afirmar que amén del consabido hito representativo del proceso revolucionario, como fuera sin duda la toma de la Bastilla, no se puede dejar de analizar que ya muchos integrantes del Tercer Estado que se encontraba compuesto por la nobleza (en oportunidad de la convocatoria de Luis XVI a los Estados Generales para la confección de listas de agravios), fueran los más efervescentes peticionantes de una declaración de derechos. ${ }^{19}$ Ello explicado desde su férreo apego a los principios del

\footnotetext{
18 Hobsbawm ob. Cit pag. 157

19 Lynn Hunt ob cit. Pag. 130.
} 
liberalismo económico, que dé por tierra con el dirigismo de la economía francesa y resalte los principios de la libertad de comercio. ${ }^{20}$

Esa tensión existente entre los presuntos motivos de la revolución y los que realmente resultaron ser los motivos preponderantes, da cuenta de la confrontación en el análisis sobre la supuesta unidad del impulso de la Revolución. Existió un objetivo, claro, hegemónico, que no tardó en ponerse al descubierto de forma predominante sobre el resto de los objetivos e intereses que motivaron la búsqueda de una Declaración de Derechos.

Lo que primero se pensó a través del relato histórico como un proceso signado por la unidad de los tres principios referidos a la libertad, igualdad y fraternidad, ha podido ser desentrañado a partir del revisionismo histórico que permitió dar cuenta del dualismo del proceso revolucionario y la victoria final del primero de los principios sostenidos por sobre los conceptos de solidaridad invocados.

" A decir la verdad, la unicidad del impulso revolucionario ( que supondría una tendencia sostenida y uniforme desde la convocatoria de los Estados Generales hasta la ulterior estabilización - y regresión - termidoriana, directorial o napoleónica) fue tempranamente cuestionada por los mismos contemporáneos. Se ha hecho habitual, desde Jaurés (cf. Jaurés 1946, tL, pp, 108-118) citar a Barnave como el primer historiador-partícipe de la Revolución Francesa, pero no se tiene suficientemente en cuenta a Buonarroti, quien desde las primeras páginas de su Conspiration muestra la naturaleza dual de un proceso que dará finalmente la victoria a una parcialidad sobre otra: en sus términos, a la "facción de los egoístas" sobre el "partido de la igualdad” (Buonarroti 1971, pp. 7-33) ${ }^{21}$

Esa unicidad lograda en los albores de la Revolución Francesa, que permitiera el emerger de quienes sostenían y pregonaban una Revolución que garantizara las condiciones necesarias para el libre comercio, se logró en los comienzos del proceso revolucionario en una etapa que no se extendió más allá de los inicios de 1794. Dicha disputa se resolvió en poco tiempo relativamente, si comparamos que la misma se mantuvo en los Estados Unidos

\footnotetext{
20 Guerin Daniel, "La lucha de clases en el apogeo de la revolución francesa" Biblioteca Militantes Ediciones, 2011, pag.123

${ }^{21}$ Sazbon, Jose “ Seis estudios sobre la revolución francesa” Ediciones al Margen, 2005, pag. 20
} 
de Norteamérica durante más de 60 años desde la proclama de la Declaración de Derechos de 1791, hasta la Guerra Civil de 1861, la que finalmente permitió la imposición de un sistema económico sobre otro con la derrota de la economía colonial y agrícola de los Estados del Sur. ${ }^{22}$

Así, es dable sostener que esa preponderancia de los mecanismos que garantizarían el sistema de libre comercio, se reflejara sin lugar a dudas en la redacción de los derechos reconocidos, tal como se pasará a analizar.

\section{3.- Derechos ¿Cuáles derechos?}

Los 17 artículos que componen la Declaración de Derechos del Hombre y del Ciudadano permiten convalidar y fundamentar las posiciones asumidas precedentemente.

Así, todo lo expuesto, queda reflejado de forma explícita en los contenidos de la propia Declaración de Derechos del Hombre y del Ciudadano donde se ven representadas las peticiones del burgués de 1789. Este documento es un manifiesto contra la sociedad jerárquica y los privilegios de los nobles, pero no a favor de una sociedad democrática o igualitaria. Los hombres nacen y viven libres e iguales bajo las leyes, dice su artículo primero, pero luego se acepta la existencia de distinciones sociales aunque sólo por razón de la utilidad común. La propiedad privada era un derecho natural sagrado, inalienable e inviolable. Los hombres eran iguales ante la ley y todas las carreras estaban abiertas por igual al talento, pero si la salida empezaba para todos sin hándicap, se daba por supuesto que los corredores no terminarían juntos. La declaración establecía (frente a la jerarquía nobiliaria y el absolutismo) que todos los ciudadanos tienen derecho a cooperar en la formación de la ley, pero o personalmente o a través de sus representantes. Ni la asamblea representativa, que se preconiza como órgano fundamental de gobierno, tenía que ser necesariamente una asamblea elegida en forma democrática, ni el régimen que implica habría de eliminar por la fuerza a los reyes. Una monarquía constitucional basada en una oligarquía de propietarios que se expresaran a través de una asamblea representativa, era más adecuada para la mayor parte de los burgueses liberales que la república democrática, que pudiera haber parecido una expresión más lógica de sus aspiraciones teóricas; aunque hubo algunos que no vacilaron en preconizar esta última. Pero, en conjunto, el clásico

\footnotetext{
${ }^{22}$ Horbsbawn Eric, ob cit. Pag 184
} 
liberal burgués de 1789 ( y el liberal de 1789-1848) no era un demócrata, sino un creyente en el constitucionalismo, en un Estado secular con libertades civiles y garantías para la iniciativa privada, gobernado por contribuyentes y propietarios. ${ }^{23}$.

Sin embargo, oficialmente nunca se reconocería la defensa irrestricta de los intereses de clase que se defienden en la declaración, sino que todo sería realizado en representación de la voluntad general “ del pueblo", al que se identificaba como la "nación francesa"

Ahora bien, la redacción y legislación de tales derechos, desoye claramente los restantes problemas que acuciaban a la sociedad francesa de fines del Siglo XVIII.

Así, sorprende que un movimiento revolucionario que argumentara tener como pilar los principios de igualdad y solidaridad, nada diga en su Declaración sobre los derechos relativos al trabajo, a un salario mínimo, al descanso semanal, a la protección de la familia. Ni se exprese sobre cuestiones que se encontraban en plena discusión al momento de la declaración de derechos, tales como: el acceso a los alimentos, las jornadas de trabajo, el abastecimiento de los productos esenciales. Todas situaciones que tuvieron su punto cúspide durante los años 1792/93 en pleno fragor revolucionario.

Mucho menos se puede decir, sobre la absoluta ausencia de discusión en lo que implicaba el derecho a la libertad de los esclavos, las minorías religiosas o las mujeres, que carecían de capacidad de verse representadas en la política antes y después de la revolución, pese a ser activas participantes e incitadoras de los albores pre-revolucionarios y revolucionarios de la convulsionada Francia de fines del Siglo XVIII.

En el caso del derecho de las mujeres, tan explícita resultaba la negativa a efectuar un reconocimiento de derechos a dicho colectivo, que quien se atrevió a publicar el Manifiesto titulado "Declaración de los Derechos de la Mujer y la Ciudadana" ${ }^{24}$, realizado por aquella precursora del feminismo, la francesa Olimpia de Gouges en 1791, padeció la gillotina dos años más tarde, acusada precisamente de contra revolucionaria.

Pero como se viene sosteniendo, estos derechos no formaron parte de la declaración deliberadamente. Ello no ha sido por mera omisión.

\footnotetext{
23 Hobsbawm, ob. Cit. pag. 67

${ }^{24}$ Cutrufelli Maria Rosa, La Ciudadana, Colección Umbriel Historica
} 
Existe una relación directa entre los derechos reconocidos en la Declaración y las necesidades expresadas por el sistema económico. Donde claramente todas las ausencias aquí mencionadas o bien no resultaban parte necesaria para el desarrollo del sistema económico pretendido o directamente afectaban los planes de liberalidad necesario para llevarlo a cabo (entiéndase primordialmente los relacionados a la regulación de las condiciones de trabajo, sobre la comercialización de los alimentos o la regulación de la propiedad privada).

El verdadero legislador no es el redactor de la ley sino el conjunto de los agentes que, determinados por los intereses y las sujeciones específicas asociadas a sus posiciones, en campos diferentes (jurídico, religiosos, político) elaboran aspiraciones elevándolas al estado de "problemas sociales”, todo lo cual será luego consagrado en el trabajo jurídico, añadiéndole el efecto de generalización y universalización que encierran la técnica jurídica. Todo ello consagra el esfuerzo de los grupos dominantes, o en ascensión, para imponer, especialmente a favor de situaciones críticas o revolucionarias, una representación oficial del mundo social que sea conforme a su visión del mundo y favorable a sus intereses.

Recuerda hablando de la Revolución Francesa, en nota, Pierre Bourdieu:

El análisis de los "libros de costumbres " y de los registros de deliberaciones comunales de un cierto número de municipios del Béarn (Arudy, Bescat, Denguin, Lacommande, Lasseube) me ha permitido ver cómo normas "universales" concernientes a los procedimientos de toma de decisiones colectiva, como el voto de la mayoría, pudieron imponerse durante la Revolución, en detrimento de la vieja costumbre, que exigía la unanimidad de los "cabezas de familia', en virtud de la autoridad que les confería el hecho mismo de su objetivación, útil para disipar las oscuridades, como la luz de las tinieblas, de los que " ni que decir tiene." ${ }^{25}$

Es así que contextualizados en el contexto económico, social y cultural en que se desarrolla la Revolución Francesa y con ello la creación de los "Derechos del Hombre y del

\footnotetext{
25 Pierre Bourdieu , Ob. Cit pag. 216
} 
Ciudadano", es que se pueden comprender los intereses que se encontraban en discusión y con ello los motivos de la primera Declaración de Derechos.

\section{Capítulo III}

\section{EI derecho construyendo derechos (o paradojas de la vida y el destino)}

\section{1.- El derecho:}

Resulta necesario e imprescindible para entender el rol del derecho en nuestra sociedad, realizar un análisis del campo del derecho como discurso, en su dimensión ideológica y en lo que respecta a su carácter legitimante y así poder adentrarnos al estudio del derecho como herramienta utilizada en el proceso de la Revolución Francesa para plasmar las conquistas civiles, políticas y económicas obtenidas mediante el mismo.

Su análisis generará sin dudas una primera contradicción, al observar que resulta ser el mismo sistema legal motivo de crítica, el que a su vez construye el sistema de protección jurídica para aquellos que se encuentran en mayor situación de vulnerabilidad. Es decir, precisamente que sea el derecho, la Ley, el poder del legislador, la burocracia judicial; todo el sistema encargado de crear, nominar y garantizar los denominados "derechos humanos", es sin lugar a dudas una fuerte contradicción con el objetivo creador del mecanismo legislativo como legitimación del poder.

La paradoja, por si se requiere que sea explicitada más aún, se hace más visible al ubicar al derecho en su rol de límite al poder absoluto y por otra parte, que sea ese mismo sistema legal el más eficaz y a la vez refinado mecanismo de dominación. Una herramienta utilizada por la clase dominante para construir la legalidad o delimitar la ilegalidad de los sistemas políticos, económicos y sociales, según sus necesidades y conveniencias.

Por ello nos surge un primer interrogante, y es si la ley ¿limita al poder o transforma el poder en orden?

Sin lugar a dudas que el derecho posee una estrecha relación con el poder, lo que merece ser descubierto es ¿de qué tipo de relación hablamos? ¿de contralor o de legitimación?.

El carácter constituyente del discurso proviene directamente de su relación con el poder. El derecho instituye, dota de autoridad, faculta a decir y a hacer, y el sentido con que 
define esta práctica está determinado por el juego de las relaciones de dominación, por la situación de las fuerzas sociales en pugna en un tiempo y en un lugar determinado. ${ }^{26}$

Precisamente la similitud del sentido común con la construcción jurídica determinada mediante la creación de la norma, no es tal por mera coincidencia o azar del destino, sino que responde con claridad al fiel reflejo de un discurso hegemónico construido por las clases dominantes y posteriormente legitimado por el sistema jurídico.

La naturalización de una práctica social construida sobre las bases de la imposición, es sin dudas un logro que ha permitido sostener la legitimidad del poder creador de la norma.

"Se sabe que lo propio de la eficacia simbólica es que solo se puede ejercer con la complicidad de los que la sufren, tanto más segura cuanto más inconsciente es, o sea, cuanto más sutilmente arrebatada"27

Así, los brujos de la modernidad ya no utilizan pócimas compuestas de restos biológicos o componentes materiales, hoy son los magistrados, los abogados, los profesores de derecho, los juristas, quienes manejan el saber especifico, conocen su lógica interna e interpretan lo que se puede o no hacer en una sociedad, y con ello conservan la autoridad de reglar y legitimar el poder.

La norma terminará diciendo lo que el poder quiere que diga.

Con suma crudeza lo resume Ferdinan Lasalle en sus famosas "Conclusiones Prácticas" al expresar que:

“ los problemas constitucionales no son primariamente, problemas de derecho, sino de poder; la verdadera constitución de un país sólo reside en los factores reales y efectivos de poder que en ese país rigen; y las Constituciones escritas no tienen valor ni son duraderas más que cuando dan expresión fiel a los factores de poder imperantes en la realidad social" . ${ }^{28}$

\footnotetext{
${ }^{26}$ Ruiz Alicia E. “Aspectos Ideológicos del Discurso Jurídico” en Materiales para una Teoría Crítica del Derecho Lexis Nexis Abeledo - Perrot 2006 pag. 117

27 Pierre Bourdieu ob cit pag. 210

${ }^{28}$ Lasalle Ferdinand ¿Qué es una Constitución? Dialogo Abierto Mexico 1996 pag. 75
} 
Y así el derecho no escapa a la determinación de sentidos y significados propios de nuestro lenguaje; sabemos que las palabras han sido inventadas siempre por las clases superiores no para indicar sólo un significado sino para imponer una interpretación. No hay un significado original que se excluya de la interpretación que oportunamente le fuera designada. $^{29}$

Y con el derecho ocurre lo mismo.

Pero está claro que lo antedicho no resulta alentador al momento de plasmar una pauta cultural y moral que deberá ser aceptada por todos. Entonces: ¿cómo lograr respeto y legitimidad social de una construcción jurídica que responde a intereses sectoriales ?

Claramente si el derecho es la legitimación del poder de los poderosos, no resulta atractivo para ser respetado, no invita a su cumplimiento, no produce empatía con la norma, ni existen mayorías que se consideren representadas en ella. Por tal motivo se oculta su realidad. Se omite expresar a viva voz su verdadero motivo de existencia y contrario a ello se construye una ilusión, un mundo donde la realidad está desplazada y en su lugar se presenta otra imagen como real. Tan real que sólo cabe pensar, juzgar, actuar en consecuencia. Actuar como si ... fuéramos libres e iguales; como si.... contratáramos en cada oportunidad en paridad de condiciones con el otro, como si... conociéramos las normas que debemos conocer, como si... nunca incurriéramos en "error de derecho" . Juzgar como si ... nuestra sentencia tuviera garantía de justicia y el fundamento de la verdad, como si... la realidad fuera lo que el discurso del derecho dice que es.

A partir de esa ilusión se constituye el sujeto autónomo que discierne, que siempre puede elegir en libertad: "libre" en sus relaciones interpersonales, "libre" integrante de grupos cuya pertenencia escoge, "libre" como ciudadano; "libre" para asociarse (siempre que sea con fines útiles, naturalmente); "libre" para ejecutar todas las acciones que el derecho no prohíbe (lo que supone que está en condiciones de poder efectivamente realizar todos esos actos). Como se ve lo ilusorio gesta lo ilusorio y lo hace con efecto multiplicador: la sociedad (espejo de los hombres que la forman) es una sociedad igualitaria, los estados soberanos tienen capacidad de autodeterminarse; los sistemas democráticos son definidos por la división de poderes y la declaración formal de garantías, la independencia del Poder Judicial, etcétera. La enumeración no es casual sino que intenta

\footnotetext{
${ }^{29}$ Nietzsche Friedrich Genealogia de la Moral Cap. I: 4 y 5
} 
llamar la atención sobre los múltiples aspectos en los que se proyecta esta fuerza mágica del derecho.

El drama social no debe aparecer. Los enfrentamientos de intereses opuestos y contradictorios no deben ser mostrados. Cada vez que su potencia fracture el gran discurso censor, éste deberá repararse sin hacerse cargo de su herida traumática, para lo cual habrá de decir algo acerca de lo que es, pero poniéndolo en un lugar diferente. Si las luchas obreras obligaron a reconocer el derecho de huelga y la organización sindical, habrá de incorporárselos, pero distanciándolos rápidamente de su origen. Su historia empieza aquí, recién aquí, en el exacto momento de su juridización. $\mathrm{O}$ al menos esto es lo que pretende, con más o menos éxito, el "discurso oficial” de los juristas. ${ }^{30}$

Estas disposiciones a, que son producto de la historia y al mismo tiempo actualización de la historia en cada acto, suponen el olvido de la historia que la misma historia produce al producir, en la socialización del agente y en la estructuración de sus estructuras estructuradas, objetivas y estructurantes, esas "cuasi-naturalezas" que son los habitus : "historia incorporada, naturalizada y, por ello, olvidada como tal historia, el habitus es la presencia activa de todo el pasado del que es producto " (Bourdieu, 2007; 92). Así, el habitus, que es producto de la historia, origina prácticas y, al originarlas, origina también historia según los esquemas previamente originados por la historia; el inconciente nunca es otra cosa, ha dicho Bourdieu (2007), que el olvido de la historia. De esta forma, las prácticas adquieren cierta independencia de las determinaciones de lo inmediato y del pasado ya pasado, olvidado como tal, pero activo a través de las disposiciones y estructurado como capital acumulado y por hacer valer. ${ }^{31}$

Refleja con claridad meridiana el periodista, escritor y militante político Rodolfo Wlash al decir:

\footnotetext{
30 Ruiz Alicia E. ob cit pag. 126

31 Schleifer Pablo, Campo científico, ciencia y uso político de la ciencia en el pensamiento de Bourdieu El sentido práctico. Buenos Aires. Siglo XXI Editores, Revista de la Facultad 14, 2008; 227-252
} 
"Nuestras clases dominantes han procurado siempre que los trabajadores no tengan historia, no tengan doctrina, no tengan héroes y mártires. Cada lucha debe empezar de nuevo, separada de las luchas anteriores: la experiencia colectiva se pierde, las lecciones se olvidan. La historia parece así como propiedad privada cuyos dueños son los dueños de todas las otras cosas". 32

Es así que podemos comenzar a explicar el surgimiento de los derechos humanos, plasmados en la Declaración de Derechos y Deberes del Hombre y el Ciudadano, en el contexto precedentemente desarrollado.

\section{2.- Los derechos:}

En esta primera Declaración de Derechos ${ }^{33}$ (con las salvedades ya referidas oportunamente), la construcción normativa que reconoció derechos no estuvo alejada de los condicionantes referidos ut supra.

Sin lugar a dudas la instauración de la Declaración de Derechos del Hombre y del Ciudadano resultó una fuerte limitación al poder absoluto, al mismo tiempo que garantizó los márgenes de acción necesarios para el desarrollo del poder económico que se consideraba oprimido por un regulación económica que, entendía, lo asfixiaba en sus potencialidades .

Limitación del poder del estado y ampliación de las prerrogativas de la burguesía para obtener su liberalización comercial, son las dos caras de una misma moneda.

El derecho no pierde así su esencia, su motivo de existir, sino que direcciona con claridad el sujeto al cual controlar y el sujeto al cual proteger.

Lo expuesto resulta necesario de ser comprendido para entender así la operatividad de los derechos creados en la Declaración de 1789.

La aparición de los derechos, la construcción jurídica que legitima su creación, no fue pensada para que los mismos carezcan de eficacia en su exigibilidad y vigencia.

Es más, sin ingresar en las discusiones sobre la fundamentación de los derechos que motivarían otro trabajo de similar extensión, es necesario recordar que la propia

\footnotetext{
32 Walsh Rodolfo, El Cordobazo “Periódico de la CGT de los Argentinos” Mayo de 1968.

${ }^{33}$ Declaración de Derechos y Deberes del Hombre y del Ciudadano 1789
} 
Declaración se encargó de resaltar la obligatoriedad del respeto y cumplimiento de las normas que allí se expresaban.

"La libertad consiste en poder hacer todo aquello que no cause perjuicio a los demás. El ejercicio de los derechos naturales de cada hombre, no tiene otros límites que los que garantizan a los demás miembros de la sociedad el disfrute de los mismos derechos. Estos límites sólo pueden ser determinados por la ley. La ley sólo puede prohibir las acciones que son perjudiciales a la sociedad. Lo que no está prohibido por la ley no puede ser impedido. Nadie puede verse obligado a aquello que la ley no ordena." 34

Por ello sostenemos que, lejos de adentrarnos en los fundamentos y justificaciones de los derechos, tanto desde visiones iusnaturalistas, positivistas o positivistas metodológicos, por nombrar algunas, la coincidencia de dichas visiones estaba dada por considerar que la sola existencia de los mismos, más allá del punto de su nacimiento (como derecho natural o por la creación mediante la norma), aseguraba el respeto y su vigencia.

Para Hans Kelsen, en su Teoría Pura lo dicho se reflejaba claramente:

" La conducta del individuo, correspondiente a la conducta obligatoria de otro individuo, es designada, con usos lingüísticos más o menos consistentes, contenido "del derecho", en cuanto objeto de una "pretensión" correspondiente a la de otro, en especial el ejercicio de la exigencia o pretensión sobre la conducta obligatoria, se suele denominar ejercicio del derecho. Sin embargo, no es corriente hablar, en caso de la obligación de omisión de determinadas acciones, como el de la obligación de omitir matar, robar, etcétera, de un derecho o pretensión jurídica a no ser muerto, no ser robado, etcétera. En el caso de la obligación de no hacer frente a determinada conducta correspondiente a la conducta de omisión obligatoria, se habla de "disfrutar" o de "gozar" del derecho; sobre todo, se habla del goce de un derecho cuando se trata de que el obligado admita que el otro use, consuma o, inclusive, destruya determinada cosa. Pero esta

\footnotetext{
${ }^{34}$ Declaración de los Derechos del Hombre y del Ciudadano arts. 4 y 5
} 
situación de hecho designada como "derecho" o pretensión jurídica de un individuo, no es otra cosa que la obligación del otro, o de los otros. Si se habla, en este caso, de un derecho subjetivo, o de la pretensión jurídica de un individuo, como si ese derecho o pretensión fuera algo distinto de la obligación del otro, o de los otros, se crea la apariencia de dos situaciones jurídicamente relevantes, cuando sólo se da una. La situación objetiva en cuestión queda descrita exhaustivamente con la descripción de la obligación jurídica del individuo (o individuos) de comportarse de determinada manera frente a otro. Decir que un individuo está obligado a determinada conducta, significa que, en el caso de un comportamiento contrario, debe producirse una sanción, su obligación es la norma que requiere esa conducta, en tanto enlaza, a la conducta contraria, una sanción. Cuando un individuo está obligado a cumplir determinada prestación a favor de otro, el contenido (objeto) de la obligación es la prestación que el otro ha de recibir, sólo se puede prestar (dar) a otro, lo que el otro reciba. Y si un individuo está obligado frente a otro, a consentir determinada conducta de este último, esa actitud pasiva es justamente el contenido de su obligación. Es decir, la conducta correspondiente del individuo en cuyo respecto existe la obligación, correspondiente a la conducta obligatoria, se encuentre también determinada ya en la conducta que configura el contenido de la obligación. Si se designa la relación de un individuo, que se encuentra obligado respecto de otro a determinada conducta, como "derecho", entonces ese derecho no es sino un reflejo de esa obligación.”35

Se considera aquí que los derechos no fueron creados para ver si se los respetaba o no.

Esa costumbre de declarar, de positivizar, remontándose a aquellas primeras prácticas de volcar y escribir sobre un papel qué actos tenía derecho a realizar el ser humano ( y también lógicamente cuáles tenía prohibidos), no fueron realizados pensando en que dicho desarrollo y elaboración no tenía fuerza de ser respetada.

Si se afirma que los derechos tienen fuerza de ley, lo cual reflejado en una máxima del derecho procesal diría que le comprenden las generales de la ley, ¿cómo pensar que

\footnotetext{
35 Kelsen Hans, Teoría Pura del Derecho, Ed. Universidad Autónoma de México 1979, Pag. 140
} 
dependen luego de la voluntad del legislador?, ¿de la interpretación judicial?, ¿o de tal o cual programa de gobierno?. Desde el mismo momento de su creación, no tendría sentido desarrollar derechos que no tuvieran por sí mismos la obligación de ser respetados.

Es que hasta simbólicamente el derecho es considerado como la solución a una necesidad. Tener derecho a algo es que el conjunto de la sociedad, donde también está el Estado, tiene la obligación de respetarlo. No se representa el derecho como prerrogativa, facultad, acceso, y a renglón seguido, sólo si luego se define de tal o cual forma. El solo convencimiento de la existencia del derecho, extiende en la sociedad la creencia de su existencia y la obligatoriedad de su respeto.

Pero entonces ¿cómo se llega hoy día a considerar que existen derechos que pueden ser respetados por su sola creación y derechos que dependen de una voluntad expresa plasmada con posterioridad en tal sentido?. ¿Cómo un derecho puede no ser obligatorio, y en definitiva funcionar a contrario de su propia definición?.

Se está frente a un contrasentido del significado propio de la palabra que lo define, un derecho al cual no se tiene derecho.

Sólo si se logra concebir este doble rol mencionado al comienzo del capítulo, donde el mismo mecanismo que define cuáles serán las acciones permitidas y obligatoriamente necesarias de ser respetadas por los hombres, será también aquel que garantice el orden en la distribución de poder y legitime su existencia en las sociedades modernas, es que se comprenderá , parafraseando a Ihering, La Fuerza del Derecho ${ }^{36}$

Bourdieu lo expresa con singular claridad:

“ Se comprende que, en una sociedad diferenciada, el efecto de universalización sea uno de los mecanismos, y sin duda uno de los más poderosos, a través de los cuales se ejerce la dominación simbólica o, si se prefiere, la imposición de la legitimidad de un orden social. Cuando consagra bajo la forma de un conjunto formalmente coherente de reglas oficiales y, por definición, sociales, universales", los principios prácticos del estilo de vida simbólicamente dominante, la norma

\footnotetext{
36Rudolf von IHERING, "La lucha por el derecho", ILSA, Bogotá, 2004, p. 55.
} 
jurídica tiende a informar realmente las prácticas del conjunto de los agentes, más allá de las diferencia de condición y de estilo de vida: el efecto de universalización, que también podríamos llamar efecto de normalización, viene a redoblar el efecto de autoridad social que ya ejercen la cultura legítima y sus detentadores para dar toda su eficacia práctica a la coacción jurídica. Mediante la promoción ontológica que opera convirtiendo la regularidad ( lo que se hace regularmente) en regla ( lo que es de ley hacer), la normalidad de hecho en normalidad de derecho .... La institución jurídica contribuye, sin duda, universalmente a imponer una representación de la normalidad en relación a la cual todas las prácticas diferentes tienden a parecer como desviadas, anómicas, o sea anormales y patológicas",37

Se usa el mismo instrumento de dominación que asegura la vigencia y continuidad del poder sin sobresaltos, para garantizar por escrito y plasmar en textos los logros obtenidos para limitar su uso.

\section{3.- Cláusulas Operativas y Programáticas}

En este contexto no se puede entonces dudar ni asombrarse de la aparición de una pauta interpretativa de los derechos como fue la creación doctrinal, y jurisprudencial después, de las cláusulas operativas y programáticas, como mecanismo de legitimar la división generada en la vigencia de los derechos según las perrogativas que garanticen.

Así, de la construcción jurídica que con su mera creación reconocía la vigencia y exigibilidad de las facultades y prerrogativas positivizadas, a la interpretación limitativa de su existencia, es que aparecen estas cláusulas que serán de ahora en más el mecanismo que justificará hacia el adentro del campo jurídico, el verdadero objetivo del derecho, como mecanismo de defensa de la clase dominante.

Mediante un compendio de las posiciones asumidas al respecto, se ha sostenido que:

\footnotetext{
${ }^{37}$ Pierre Bourdieu , Ob. Cit pag 213
} 
"En la doctrina constitucional, en general ( p. ej. Ekmedjian M A Manual,, pags. 76/78, Quiroga Lavie, Derecho Constitucional, pag. 138/150, Sagues Pedro Nestor, Elementos... T 1 pags 92/94, entro otros), se sostiene que las cláusulas constitucionales son operativas cuando están dirigidas a una situación de la realidad en la cual puedan operar inmediatamente, sin necesidad de instituciones que deba establecer el Congreso, que dicha operatividad puede surgir de la propia norma constitucional (Self - Ejecuting) o requiere de una ley para trasformar, como dice Ejmedjkian, la "potencia en acción". Generalmente se las identifica con las normas que generan prestaciones de no hacer. En cambio, las normas programáticas, son de aquellas que no habilitan la protección jurisdiccional al beneficiario y que, necesariamente, requieren de una norma inferior para obtener operatividad derivada. Se las identifica con normas que ordenan dar o hacer". ${ }^{38}$

Así, se engloba dentro de las cláusulas constitucionales operativas a todos los derechos que reconocidos constitucionalmente no requieren para su exigibilidad y vigencia de una norma infraconstitucional que lo reglamente o determine en las condiciones de su vigencia, queda incluida así la clásica concepción de los derechos, desde su creación, incluso antes de la otrora clasificación mencionada, donde la mera positivización de la norma, generaba el cumplimiento y respeto hacia quienes titularizaban el derecho.

Allí se encuentran, en el lugar que ingresaron desde su creación y del que nunca se fueron, los derechos reconocidos en la Declaración de los Derechos del Hombre y del Ciudadano como ser el derecho a la libertad de expresión, la igualdad ante la ley, la propiedad privada, derechos sobre los cuales nunca se puso en discusión la capacidad de su imperativo constitucional de obligatorio cumplimiento.

En contraste a lo expuesto, la aparición de los derechos enmarcados como programáticos, obedeciendo a los motivos de esta construcción, daban dentro de su carácter de derechos promesas, derechos programas, la pauta de su restricción legal al momento de plantear la obligatoriedad de su cumplimiento. Tales derechos como el acceso a la vivienda propia, al trabajo, a la seguridad social, a la alimentación serán reconocidos siempre y

\footnotetext{
38 Wlasic Juan Carlos Manual Critico de Derechos Humanos 2da. Edición Actualizada y Ampliada, La Ley 2011, pag. 48
} 
cuando se los enmarque en esta nueva clasificación de derechos, específicamente creada al efecto.

Dichas cláusulas fueron fundamentadas desde el posicionamiento que implica sostener que los derechos civiles y políticos genera exclusivamente obligaciones negativas o de abstención, es decir implican un no hacer de parte del Estado, no detener a una persona, no impedir la libre circulación de ideas, no turbar la propiedad privada, y por otro lado los derechos económicos, sociales y culturales donde las obligaciones del Estado se caracterizaría por sus obligaciones de hacer, de prestación positiva del Estado, como proveer prestación de salud, garantizar el acceso a la educación, construir viviendas para quienes no acceden por sus propios medios. Por lo que no es la abstención la característica de estos últimos sino que el Estado debe erogar recursos para cumplimentar con los mismos.

Vale aclarar, sin perjuicio del desarrollo en el acápite que precede, que tal argumentación carece de sustento fáctico.

Estas distinciones están basadas sobre una visión totalmente sesgada y naturalista del rol y funcionamiento del aparato estatal, que coincide con la posición decimonónica del Estado mínimo, garante exclusivamente de la justicia, la seguridad y la defensa. Sin embargo, incluso para los pensadores más caracterizados de la economía política clásica, como Adam Smith y David Ricardo, resultaba más que obvia la interrelación entre las supuestas “obligaciones negativas" del Estado, en especial en materia de garantía de la libertad de comercio y una larga serie de obligaciones positivas, vinculadas con el mantenimiento de las instituciones políticas, judiciales, de seguridad y defensa, necesarias como condición del ejercicio de la libertad individual. En Smith, por ejemplo, se asigna al Estado un rol activo en la creación de las condiciones institucionales y legales para la consolidación del funcionamiento y expansión del mercado. Lo mismo cabe señalar con respecto a muchos otros derechos "civiles y políticos": el respeto de derechos tales como el debido proceso, el acceso a la justicia, el derecho a casarse, el derecho de asociación, el derecho de elegir y ser elegido, suponen la creación de las respectivas condiciones institucionales por parte del Estado (existencia y mantenimiento de tribunales, establecimiento de normas y registros que hagan jurídicamente relevante la decisión nupcial o el acto de asociación, convocatoria a elecciones, organización de un sistema de 
partidos políticos, etc) . Aún aquellos derechos que parecen ajustarse más fácilmente a la caracterización de "obligaciones negativas", es decir, los que requieren una limitación en la actividad del Estado a fin de no interferir la libertad de los particulares - por ejemplo, la prohibición de detención arbitraria, la prohibición del establecimiento de censura previa a la prensa, o la prohibición de violar la correspondencia y los papeles privados - , conllevan una intensa actividad estatal destinada a que otros particulares no interfieran esa libertad y al restablecimiento de la libertad o la reparación del perjuicio una vez producida una interferencia indebida, de modo tal que la contracara del ejercicio de estos derechos está dada por el cumplimiento de funciones de policía, seguridad, defensa y justicia por parte del Estado. Evidentemente, el cumplimiento de esas funciones reclama el cumplimiento de obligaciones positivas, caracterizadas por la erogación de recursos y no la mera abstención del Estado. ${ }^{39}$

\section{Capítulo IV.}

\section{Génesis de los Derechos Económicos, Sociales y Culturales}

\section{1.- Y aparece el Comunismo}

Como se expresara desde el inicio, la presente tesis procurar explicar el actual estado de exigibilidad y vigencia de los Derechos Económicos, Sociales y Culturales (DESC), para lo cual resulta de vital trascendencia analizar el contexto histórico en el que surgen los mismos.

El mundo de comienzos del Siglo XX se encuentra en pleno apogeo de producción, en los hechos, desde las enseñanzas del liberalismo económico desarrolladas y elaboradas a mediados del Siglo XIX. Ante ello, el avance del sistema económico capitalista provocó como contrapartida el diseño de un sistema económico donde la economía planificada y el control de los medios de producción se alzaban por sobre los principios del libre mercado y la liberalidad económica. Comenzó así a elaborarse el sustento teórico para contrarrestar el desarrollo capitalista.

La aparición en 1848 del Manifiesto Comunista ${ }^{40}$ fue sin dudas un hito de trascendencia mundial que signó la contraposición de un sistema económico alternativo al

\footnotetext{
${ }^{39}$ Abramovich Victor - Courtis Christian Los derechos sociales como derechos exigibles Ed. Trotta 2004 pag. 23

40 Marx Carlos y Engels Federico, Manifiesto Comunista, Ed. Nuestra América 2004.
} 
capitalismo de mercado, el cual se encontraba en pleno auge de expansión al momento de su aparición.

La lucha de clases, los conceptos de proletariado, mercancía, socialismo, serán el pilar de desarrollo de toda una teoría económica que encontrara su cúspide con la aparición de El Capital. ${ }^{41}$

Si bien aparece ya en la Revolución de 1871 en Francia y el gobierno de las comunas el primer intento por consolidar y llevar adelante un gobierno del proletariado, con sustento en una economía socialista, es sin lugar a dudas la Revolución Rusa de 1914/17 la que logra llevar a la práctica el socialismo real.

Por primera vez se ponía seriamente en riesgo la continuidad del sistema económico capitalista. La organización popular, sobre todo a través de las organizaciones sindicales de origen comunista y anarquista de comienzos del Siglo XX, tenía ante sí la comprobación más palpable de que el Comunismo, como sistema económico y social, era posible de ser implementado.

El paso de la lexis a la praxis trajo inmediatamente sus consecuencias hacia el adentro de las económicas de mercado.

El aumento de la conflictividad social producto de la mayor organización popular que ponía en discusión el sistema de acumulación capitalista, puso en serio riesgo el sistema de paz y orden, imprescindibles para una disciplinar organización social del trabajo, todo lo cual alteraba las bases mismas del sistema centrípeto de acumulación capitalista.

Sin lugar a dudas la aparición del socialismo real modificó sustancialmente el orden social, económico y político imperante hasta entonces, por lo que semejantes transformaciones en todos esos órdenes no tardaron en volcarse al derecho.

La relación se invirtió, por un lado en el capitalismo la Revolución Francesa resultó el hito indispensable, con su Declaración de Derechos del Hombre y del Ciudadano, para generar las condiciones propicias al desarrollo de una economía liberal de mercado. En el otro proceso, primero efectuó su aparición el Comunismo, como sistema económico y como nuevo orden social, y luego recién después surgió la positivización de los DESC.

\section{2.- Como derechos sí}

\footnotetext{
${ }^{41}$ Marx Carlos El Capital Tomos I, II y III Siglo XIX Editores
} 
El capitalismo requirió y se sirvió de los DD.HH para propender al desarrollo del sistema capitalista, sin lugar a dudas resultaron ser el sustento normativo que permitió el desarrollo exponencial del sistema, fueron los derechos a la libertad de mercado, al libre tránsito, a la protección de la propiedad privada, los que crearon las condiciones de su desarrollo como sistema económico imperante. En contraposición a ello, la aparición de los DESC, no fue para fortalecer el nuevo sistema económico que había hecho su aparición en la práctica con el advenimiento de la Revolución Rusa, sino por el contrario como mecanismo de salvaguarda del sistema capitalista.

Es por ello que se sostiene que los reclamos por una distribución de los beneficios de la producción, la apropiación de los recursos generados por el sistema, la supresión de los mecanismos de opresión, fueron traducidos a la lengua de los derechos con el fin de contrarrestar los argumentos de quienes consideraban a los mismos como aspiraciones comunitarias, que de ninguna forma podían restringir los Derechos Civiles y Políticos. ${ }^{42}$

La creación de los derechos como mecanismo de regulación de la convivencia social, y su fundamentación de protección de los más necesitados, había calado hondo en el imaginario social, por lo que los derechos se convirtieron en el mecanismo idóneo de protección de la población sobre el avance del Estado, todo lo cual llevó al convencimiento de que toda propuesta de restricción a los mismos, no podía ser llevada adelante sino a partir del reconocimiento y creación de nuevos derechos.

La idea de que los derechos solo conocen como límites otros derechos, indujo a las crecientes organizaciones gremiales a plantear sus reclamos sociales en el lenguaje de los derechos, de modo que pudiera decirse que el conflicto entre esas demandas era un conflicto de derecho contra derecho y no de derecho contra "utilidad general". Todo ello, partiendo de la base de legitimar el derecho como regulador del orden social, desconociendo o no atendiendo en debida forma su fuerte rol legitimante del poder de las clases dominantes en el seno del orden social.

Los intereses que se ven reflejados en la legislación, difícilmente puedan no reflejar los intereses de las clases dominantes, atento a las condicionalidades propias de su elaboración.

42 Existen Derchos Sociales Fernando Atria XVI Jornadas Argentinas de Filosofia Jurídica y Social 24,25 y 26 de Octubre del 2006.- 
“ El verdadero legislador no es el redactor de la ley sino el conjunto de los agentes que, determinado por los intereses y las sujeciones específicas asociadas a sus posiciones en campos diferentes (campo jurídico, pero también campo religioso, campo político, etc), elaboran aspiraciones o reinvindicaciones privadas y oficiosas, las elevan al estado de "problemas sociales", y organizan las expresiones (artículos de prensa, obras, manifestaciones, peticiones, marchas, etc.) destinadas a "hacerlas avanzar" 43

Explicamos ya la trascendencia del Derecho en su doble vertiente, por un lado como mecanismo de legitimación del poder, y a su vez, como mecanismo protectorio de los más desprotegidos, propio de la ilusión necesaria de ser generada como forma de obtener el consenso social necesario para su existencia.

Ahora bien, esta "estrategia", vino de la mano de la creación de las mencionadas cláusulas constitucionales operativas y programáticas, reforzadas también por el desarrollo de la llamada Teoría de las Generaciones de Derechos, que en la práctica no significó otra cosa que la construcción de una jerarquización de unos sobre otros, en tanto resulten funcionales al desarrollo del sistema capitalista o no.

Así, se impuso que las reclamaciones sociales ya solo se podían realizar en la esfera de los derechos, pero con la particularidad de que los "nuevos derechos", entiéndase los Desc, no legitimaban a la persona para reclamar su exigibilidad y vigencia, sino solo como promesa de ser desarrollados por parte del Estado.

Con una mirada clásica, el filosofo del derecho Ronald Dworkin, nos refiere claramente que

"Los derechos individuales son triunfos políticos en manos de los individuos .

Los individuos tienen derechos cuando, por alguna razón, una meta colectiva no es justificación suficiente para negarles lo que, en cuanto individuos, desean tener

${ }^{43}$ Pierre Bourdieu Ob cit. Pag. 215 
o hacer, o cuando no justifica suficientemente que se les imponga alguna perdida o perjuicios" ${ }^{\text {" } 4}$.

El reconocimiento entonces en el lenguaje de los derechos a los Desc, no fue ni más ni menos que la legitimación del sistema económico, social, cultural y político imperante, desde que tal reconocimiento vino de la mano con las construcciones jurídicas que ponían en tela de juicio su operatividad, evitando toda restricción a la imposición de las reglas del libre mercado.

Fue así como la aparición de los Desc. permitió legitimar una vez más al sistema económico vigente y limitar la posibilidad de un cambio del mismo .

El reconocimiento de algunas de las reclamaciones sociales que eran el caldo de cultivo para la ruptura del patrón de acumulación capitalista sirvió como forma de descomprimir las tensiones sociales existentes, dividir a las organizaciones obreras entre aquellas que solo veían posible la obtención de sus objetivos por el cambio radical del sistema de producción y aquellas que vieron en los Desc. una forma de obtener las mejoras sociales de los trabajadores.

Con la inteligencia que se reconoce a los creadores del derecho, su aparición una vez más permitió la legitimación del sistema.

Ahora el derecho, "levantaba las banderas" de las mejoras reclamadas por los trabajadores, las traducía en normas jurídicas, les concedía reconocimiento legal y como resultado el sistema económico capitalista garantizaba su continuidad y permanencia.

Una vez más el derecho legitima al poder, esta vez, bajo el disfraz de la protección jurídica de los más necesitados.

Desde la aguda critica efectuada por Carlos Marx en lo que hace a los derechos del hombre, y al derecho en general como sistema de dominación ${ }^{45}$, la idea del Fetichismo Legal colabora en la interpretación de la situación previamente descrita. Dicha ayuda interpretativa se profundiza más aún al permitir comprender cómo parte de este fetichismo legal, es impuesto por las clases dominantes con la finalidad de convencer a las clases

\footnotetext{
${ }^{44}$ Ronald Dworkin Los Derecho en Serio, Ed. Planeta Agostini pag. 37

45 Karl Marx Sobre La Cuestión Judía Ciencias Sociales Prometeo 2004 pag. 31 y Critica del Programa de Gotha , Ateneo Buenos Aires 1973 Pags. 33-34
} 
dominadas, que su modificación, su utilización, redundará en una mejora directa de su situación social. ${ }^{46}$

El derecho obtiene así el depósito de confianza de las clases dominadas como mecanismo eficaz de protección de sus derechos, tanto por la positivización de los mismos (creación de los Desc), como por la existencia y vigencia de los órganos judiciales que operan discursivamente en tal sentido.

Es decir, bajo el establecimiento de un sistema económico inequitativo e injusto, las reformas legislativas son expresadas como un logro en procura de una mejora en la distribución de los beneficios económicos y sociales, cuando en realidad las mismas son parte de una misma estructura de opresión.

En igual sentido, se ha expresado Mark Tushenet, al decir:

"El derecho es un instrumento del dominio social, económico y político, tanto en el sentido de apoyar los intereses concretos de los dominadores, así como en el de legitimar el orden social existente". ${ }^{47}$

Por ello, el riesgo que nos plantean las luchas que se suscitan en determinado espacio de tiempo, es el apartamiento a las estrategias colectivas, en tanto avances y repliegues de las luchas populares, y termine por conformar un fetiche legal, generando espacios que limiten la modificación de las bases de sustentación del sistema, mediante la aplicación de reformas jurídicas. Este envilecimiento por el derecho, reproduce el tan mencionado desvío de objeto del deseo, poniendo todas las esperanzas en el sistema jurídico y desalentando así la procura del cambio social mediante la lucha política. Es que a no dudarlo, tal como sostienen algunas críticas al psicoanálisis, el mismo puede provocar la adaptabilidad del individuo al medio circundante, corriendo el serio riesgo de que dicha adaptación, se realice sobre la base del convencimiento de resultar imposible la

46 Para una mayor profundización de la cuestión ver "Fetichismo Legal Derecho, violencia y movimientos sociales en Colombia Por Julieta Lemaitre Universidad de los Andes, Bogota Sela 2007.${ }^{47}$ Mark Tushenet en Roemer Andres Introducción al Análisis Económico del Derecho Mexico Fondo de Cultura Económica 1994 Pag. 75 
modificación del medio y la conveniencia de la adaptación del individuo para una mejor y más confortable supervivencia ${ }^{48}$.

Algo así como el ejemplo de Elster ${ }^{49}$ de la zorra y las uvas, en el cual la zorra, viendo que no llega a alcanzar las uvas, se termina autoconvenciendo de que éstas estaban verdes, terminando por adaptar sus preferencias a lo que ve como probable y posible.

\section{Capítulo V.}

\section{Estado Actual}

1.- ¿Son derechos o no lo son?

Hay una discusión que no se puede soslayar y que será afrontada sin perjuicio del posicionamiento expresado desde el inicio de la presente al reconocer la existencia de los Desc. (coherentes también con lo establecido por nuestro sistema legal). En ella se encuentran autores norteamericanos preponderantemente, y entre ellos Robert Nozick es seguramente uno de sus más encumbrados defensores, sosteniendo la inexistencia de los Desc. atento a desconocer la existencia de derechos positivos. Esto es, niegan la posibilidad de tener derecho a ser asistido en las necesidades básicas insatisfechas.

"Mis conclusiones principales sobre el Estado son que un Estado mínimo, limitado a las estrechas funciones de protección contra la violencia, el robo y el fraude, de cumplimiento de contratos, etcétera, se justifica; que cualquier Estado más extenso violaría el derecho de las personas de no ser obligadas a hacer ciertas cosas y, por tanto, no se justifica; que el Estado mínimo es inspirador, asi como correcto. Dos implicaciones notables son que el Estado no puede usar su aparato coactivo con el propósito de hacer que algunos ciudadanos ayuden a otros o para prohibirle a la gente actividades para su propio bien o protección. ${ }^{50}$

Tal postura, responde a concepciones que denominadas libertarias, se identifican ius- filosóficamente con un liberalismo conservador donde el estado ocupa un rol mínimo,

\footnotetext{
48 Lillio Jose Luis, Psicoanalisis y Marxismo, http://www.temasdepsicoanalisis.org/

${ }^{49}$ Elster (1983) citado en “Las Teorías de la Justicia después de Rawls” Roberto Gargarella Pag. 103

${ }^{50}$ Nozic Robert Anarquía, Estado y utopía, Basic books, Inc. Nueva York 1974, pag. 7
} 
como único garante de la libertad negativa de las personas, solo para resguardar el derecho de que nadie interfiera su libertad, pero sin derecho a la prestación de servicios esenciales.

Este endiosamiento de la libertad, permite justificar la ausencia del Estado en su rol primordial de prestaciones sociales, y con ello descartar la existencia de derechos que, como los Desc, ponen en cabeza del Estado obligaciones de prestación.

“Afirmar que los derechos son sólo negativos implica creer exclusivamente en derecho de no interferencia - derecho a que otros no me dañen, en un sentido amplio del término - y a la vez rechaza la existencia de derechos positivos, esto es, derecho a que otros me asistan en algunas necesidades básicas - derecho a que me provean de lo que necesito para vivir- . Los únicos derechos positivos concebibles son aquellos que resultan de las transacciones voluntarias entre las personas (como los que aparecen cuando contrato un cierto servicio asistencial ). Por otra parte, decir que los derechos actúan como restricciones laterales frente a las acciones de otros implica sostener el criterio liberal según el cual la esfera de los derechos ha de resultar inviolable frente a las pretensiones de los demás. Dicha esfera debe ser protegida con independencia de las consecuencias (negativas para el llamado bien común o bienestar general ) que dicha protección pueda generar. Finalmente, la idea de que los derechos son exhaustivos significa que ellos vencen frente a cualquier otra consideración moral. La idea, en este caso, es que - la filosofía política sólo se ocupa de las obligaciones exigibles y que ellas se agotan con los derechos - no existe la posibilidad de otorgar, por ejemplo, prioridad moral a la preservación del medio ambiente desplazando algún derecho de propiedad ya asignado ${ }^{.51}$

Se llega a dicho desarrollo a partir de la construcción de una particular teoría del Estado de Naturaleza donde la justificación del Estado, sólo se legitima por la existencia de lo que define como un Estado Ultramínimo.

51 Cap. Teoría de la justicia como una Teoría Insuficientemente Liberal pag. 47 
*... el defensor del estado ultramínimo puede colocar la no violación de derechos como una restricción a la acción, más que (o además de) integrarlo al estado final por realizar. La posición sostenida por este defensor del Estado ultramínimo será congruente, si su concepción de derechos sostiene que forzarle, a usted, a contribuir al bienestar de otros, viola sus derechos, mientras que, el que alguien no proporcione a usted las cosas que necesita imperiosamente, incluyendo cosas esenciales para la protección de sus derechos, no viola por sí mismo sus derechos, aún si esto evita que sea más difícil para alguien violarlos. (Esta concepción será consistente siempre que no conciba que el elemento monopólico del Estado ultramínimo es, en sí mismo, una violación de derechos.) ${ }^{.52}$

Contrariamente a lo sostenido por la posición referida, sin apartarnos de la teoría crítica del derecho y del marco teórico elegido que permite comprender cómo la relativa autonomía del campo jurídico toma relevancia en el caso de los Desc, la existencia de los mismos como derechos y precisamente como causal de justificación de la existencia del Estado es una posición asumida aquí y desde la cual surge la realización de la presente tesis.

2.- Los derechos sociales en tanto derechos

Como han sostenido trabajos especializados sobre el tema que nos convoca ${ }^{53}$, gran parte de la tradición constitucional iberoamericana en materia de derechos sociales se caracteriza por la repetición de tópicos que, a la luz de la experiencia internacional y de la ya considerable acumulación de precedentes nacionales, han demostrado ser prejuicios de tipo ideológico, antes que argumentos sólidos de dogmática jurídica.

Así, aunque la gran mayoría de las Constituciones de América Latina, la de España y la de Portugal estén alineadas dentro del denominado constitucionalismo social, se ha repetido hasta el hartazgo que las normas que establecen derechos sociales son sólo normas

\footnotetext{
52 Ibid pag. 42

53 Abramovich, C. y Courtis, C., Los derechos sociales como derechos exigibles, cit., Cap. 1.; Hacia la exigibilidad de los derechos económicos, sociales y culturales. Estándares internacionales y criterios de aplicación ante los tribunales locales", en Abregu, M, y Courtis, C., La aplicación de los tratados internacionales sobre derechos humanos por los tribunales locales, Ed. Del Puerto/CELS, Bs. As., 1997, pp. 283-350.
} 
programáticas, que no otorgan derechos subjetivos en el sentido tradicional del término, o que no resultan justiciables. De este modo, se traza una distinción entre el valor normativo de los denominados derechos civiles -o derechos de autonomía, o derechos-libertades-, que sí se consideran derechos plenos, y los derechos sociales, a los que se asigna un mero valor simbólico o político, pero poca virtualidad jurídica.

Sin embargo, la cuestión dista de ser tan sencilla. Las supuestas distinciones entre derechos civiles y derechos sociales no son tan tajantes como pretenden los partidarios de la doctrina tradicional. La principal diferencia que señalan los partidarios de dicha doctrina reside en la distinción entre obligaciones negativas y positivas (tal como se adelantara en Cap. III/ 3): de acuerdo a esta línea de argumentación, los derechos civiles se caracterizarían por establecer obligaciones negativas para el Estado -por ejemplo, abstenerse de matar, de torturar, de imponer censura, de violar la correspondencia, de afectar la propiedad privada- mientras que los derechos sociales exigirían obligaciones de tipo positivo -por ejemplo, dar prestaciones de salud, educación o vivienda-

En el primer caso, se dice, el Estado cumpliría su tarea con la mera abstención, sin que ello implique la erogación de fondos, y por ende, el control judicial se limitaría a la anulación de aquellos actos realizados en violación a aquella obligación de abstención.

Contra la exigibilidad de los derechos sociales, aún cuando tengan reconocimiento constitucional, se dice que como se trata de derechos que establecen obligaciones positivas, su cumplimiento depende de la disposición de fondos públicos y que por ello el Poder Judicial no podría imponer al Estado el cumplimiento de conductas de dar o hacer. La distinción, sin embargo, es notoriamente endeble. Todos los derechos, llámense civiles, políticos, económicos o culturales tienen un costo y prescriben tanto obligaciones negativas como positivas. Los derechos civiles no se agotan en obligaciones de abstención por parte del Estado: exigen conductas positivas, tales como la reglamentación -destinada a definir el alcance y las restricciones de los derechos-, la actividad administrativa de regulación, el ejercicio del poder de policía, la protección frente a las interferencias ilícitas del propio Estado y de otros particulares, la eventual imposición de condenas por parte del Poder Judicial en caso de vulneración, la promoción del acceso al bien que constituye el objeto del derecho. Baste repasar mentalmente la gran cantidad de recursos que destina el Estado a la protección del derecho de propiedad: a ello se destina gran parte de la actividad de la 
justicia civil y penal, gran parte de la tarea policial, los registros de la propiedad inmueble, automotor y otros registros especiales, los servicios de catastro, la fijación y control de zonificación y uso del suelo, etcétera. Todas estas actividades implican, claro está, un costo para el Estado sin el cual el derecho no resultaría inteligible y su ejercicio carecería de garantía. Esta reconstrucción puede replicarse con cualquier otro derecho -piénsese, en materia de derechos políticos, la gran cantidad de conductas positivas que debe desarrollar el Estado para que el derecho de votar pueda ser ejercido por todos los ciudadanos- . Amén de ello, muchos de los llamados derechos civiles se caracterizan justamente por exigir la acción y no la abstención del Estado: piénsese, por ejemplo, en el derecho a contar, en caso de acusación penal, con asistencia letrada costeada por el Estado en caso de carecer de recursos suficientes, o en el derecho a garantías judiciales adecuadas para proteger otros derechos.

En sentido simétrico, los derechos sociales tampoco se agotan en obligaciones positivas: al igual que en el caso de los derechos civiles, cuando los titulares hayan ya accedido al bien que constituye el objeto de esos derechos -salud, vivienda, educación, seguridad social- el Estado tiene la obligación de abstenerse de realizar conductas que lo afecten. El Estado afectará el derecho a la salud, o a la vivienda, o a la educación, cuando prive ilícitamente a sus titulares del goce del bien del que ya disponían, sea dañando su salud, excluyéndolos de los beneficios de la seguridad social o de la educación, del mismo modo en que afecta el derecho a la vida, o la libertad de expresión, o la libertad ambulatoria, cuando interfiere ilegítimamente en el disfrute de esos bienes. Ciertamente, algunos derechos sociales se caracterizan principalmente por exigir del Estado acciones positivas - $v$. gr., los llamados derechos-prestación, es decir, aquellos que requieren la distribución de algún tipo de prestación a sus titulares, como el servicio educativo o la asistencia sanitaria-, pero como hemos visto, esto también sucede con los derechos civiles que exigen prestaciones de la administración de justicia, o de los registros civiles, o del registro de la propiedad, o de las fuerzas de seguridad-. Otros derechos sociales, sin embargo -en especial aquellos caracterizados por regir aún en las relaciones entre particulares-, difícilmente puedan conceptualizarse de modo adecuado sólo como derechos prestacionales: piénsese en el derecho de huelga, o en el derecho a negociación colectiva. 
Estos derechos requieren expresamente abstenciones del Estado: no interferir en la huelga, no interferir en las tratativas ni en el resultado de la negociación.

Todo derecho, entonces, requiere para su efectividad obligaciones positivas y negativas. En línea con esta idea, autores como Fried van Hoof o Asbjorn Eide ${ }^{54}$ proponen un esquema interpretativo consistente en el señalamiento de "niveles" de obligaciones estatales, que caracterizarían el complejo que identifica a cada derecho, independientemente de su adscripción al conjunto de derechos civiles o al de derechos sociales. De acuerdo a la propuesta de van Hoof, por ejemplo, podrían discernirse cuatro "niveles" de obligaciones: obligaciones de respetar, obligaciones de proteger, obligaciones de asegurar y obligaciones de promover el derecho en cuestión. Las obligaciones de respetar se definen por el deber del Estado de no injerir, obstaculizar o impedir el acceso al goce de los bienes que constituyen el objeto del derecho. Las obligaciones de proteger consisten en impedir que terceros interfieran, obstaculicen o impidan el acceso a esos bienes. Las obligaciones de asegurar suponen asegurar que el titular del derecho acceda al bien cuando no puede hacerlo por sí mismo. Las obligaciones de promover se caracterizan por el deber de desarrollar condiciones para que los titulares del derecho accedan al bien.

Ninguno de estos niveles puede caracterizarse únicamente a través de las distinciones obligaciones positivas/obligaciones negativas, $u$ obligaciones de resultado/obligaciones de medio, aunque ciertamente las obligaciones de respetar están fundamentalmente ligadas a obligaciones negativas o de abstención, y las obligaciones de proteger, asegurar y promover involucran un mayor activismo estatal, y por ende, un número mayor de obligaciones positivas o de conducta. Este marco teórico, entiende van Hoof, refuerza la unidad entre los derechos civiles y políticos y los derechos económicos, sociales y culturales, pues los distintos tipos de obligaciones estatales pueden ser hallados en ambos pares de derechos. Por ejemplo, señala van Hoof, la libertad de expresión no requiere sólo el cumplimiento de la prohibición de censura sino que exige la obligación de crear condiciones favorables para el ejercicio de la libertad de manifestarse -mediante la protección policial-, y del pluralismo de la prensa y de los medios de comunicación en general. Paralelamente los derechos económicos, sociales y culturales no requieren

\footnotetext{
${ }^{54}$ Abramovich
} 
solamente obligaciones de garantizar o de promover, sino que también exigen un deber de respeto o de protección del Estado.

El carácter de obligaciones negativas y positivas y a cargo del Estado, en relación a los derechos consagrados en la CADH, que incluye los Desc, (art. 26) ha sido reiteradamente reconocido por la Corte IDH en la disposición del art. 1.1 del referido instrumento internacional, de jerarquía constitucional en nuestro país, que establece la obligación de respetar (negativa) y garantizar (positiva) los referidos derechos. Del mismo modo la Declaración de Viena de 1993, generadora de derecho consuetudinario internacional, ha afirmado el carácter interrelacionado e interdependiente de todos los derechos humanos, sean estos civiles y políticos o económicos, sociales y culturales. Así también lo ha entendido la Corte IDH al exigir el cumplimiento por parte del Estado de determinados Desc como forma de dar plena efectividad al derecho a la vida o la integridad personal. (arts. 4 y $5 \mathrm{CADH})$.

Por último, el Comité de Desc al examinar, en su Observacion General $N^{o} 3^{55}$, del principio de progresividad, señaló que este se integra con la regla de no regresividad y que su contenido no excluye la existencia de un núcleo básico, en cada derechos ESC, de cumplimiento efectivo e inmediato.

La propia CSJN ha señalado que en su actuación, ninguno de los poderes del Estado puede ignorar la posible generación de responsabilidad internacional por un obrar contrario a los instrumentos internacionales de derechos humanos y su interpretación por los órganos internacionales de fiscalización ${ }^{56}$.

Así tenemos que, en muchos casos, las violaciones de derechos económicos, sociales y culturales provienen del incumplimiento de obligaciones negativas por parte del Estado -ligadas, en muchos casos, a la violación de obligaciones de respeto-.

Además de algunos de los ejemplos mencionados más abajo, resulta útil recordar que uno de los principios liminares establecidos en materia de derechos económicos, sociales y culturales es la obligación estatal de no discriminar en el ejercicio de estos derechos (cfr. art. 2.2 del PIDESC), que de hecho establece importantes obligaciones

\footnotetext{
55 OBSERVACIÓN GENERAL 3 (1990) La índole de las obligaciones de los Estados Partes (Articulo 11 del Pacto Internacional de Derechos Económicos, Sociales y Culturales) http://www2.ohchr.org/english/bodies/cescr/comments.htm

56 CSJN- "Edmedkjian c/ Sofovich-1992; “Giroldi”-1995, "Sanchez María del Carmen”-2005, entre otros
} 
negativas para el Estado. El incumplimiento de este tipo de obligaciones abre un enorme campo de justiciabilidad para los derechos económicos sociales y culturales, cuyo reconocimiento pasa a constituir un límite y por ende un estándar de impugnación de la actividad estatal no respetuosa de dichos derechos. Piénsese, por ejemplo, en la violación por parte del Estado del derecho a la salud, a partir de la contaminación del medio ambiente realizada por sus agentes, o en la violación del derecho a la vivienda, a partir del desalojo forzoso de habitantes de una zona determinada sin ofrecimiento de vivienda alternativa, o en la violación del derecho a la educación, a partir de la limitación de acceso a la educación basada en razones de sexo, nacionalidad, condición económica u otro factor discriminatorio prohibido, o en la violación de cualquier otro derecho de este tipo, cuando la regulación en la que se establecen las condiciones de su acceso y goce resulte discriminatoria. En estos casos, resultan perfectamente viables muchas de las acciones judiciales tradicionales, llámense acciones de inconstitucionalidad, de impugnación o nulidad de actos reglamentarios de alcance general o particular, declarativas de certeza, de amparo o incluso de reclamo de daños y perjuicios. La actividad positiva del Estado que resulta violatoria de los límites negativos impuestos por un determinado derecho económico, social o cultural resulta cuestionable judicialmente y, verificada dicha vulneración, el juez decidirá privar de valor jurídico a la acción o a la manifestación de voluntad del Estado viciada, obligándolo a corregirla de manera de respetar el derecho afectado

Por otro lado, nos enfrentamos a casos de incumplimiento de obligaciones positivas del Estado, es decir, omisiones del Estado en sus obligaciones de realizar acciones o adoptar medidas de protección y aseguramiento de los derechos en cuestión.

Este es el punto en el que se plantea la mayor cantidad de dudas y cuestionamientos al respecto de la justiciabilidad de los derechos económicos, sociales y culturales. La cuestión presenta, sin embargo, una multiplicidad de facetas, que conviene repasar. Puede concederse que en el caso límite, es decir, el incumplimiento general y absoluto de toda obligación positiva por parte del Estado, resulta sumamente difícil promover su cumplimiento directo a través de la actuación judicial. Cabe otorgar razón a algunas de las habituales objeciones efectuadas en esta materia: el Poder Judicial es el menos adecuado para realizar planificaciones de política pública, el marco de un caso judicial es poco apropiado para discutir medidas de alcance general, la discusión procesal genera problemas 
dado que otras personas afectadas por el mismo incumplimiento no participan del juicio, el Poder Judicial carece de medios compulsivos para la ejecución forzada de una sentencia que condene al Estado a cumplir con la prestación omitida para todos los casos involucrados, o bien para dictar la reglamentación omitida, etcétera.

Ahora bien, aún admitiendo las dificultades, cabe señalar algunas matizaciones a estas objeciones. En principio, resulta difícilmente imaginable la situación en la cual el Estado incumpla total y absolutamente con toda obligación positiva vinculada con un derecho social. Como hemos dicho párrafos atrás, el Estado cumple en parte con derechos tales como el derecho a la salud, a la vivienda o a la educación, a través de regulaciones que extienden obligaciones a particulares, interviniendo en el mercado a través de reglamentaciones y del ejercicio del poder de policía, a priori (a través de autorizaciones, habilitaciones o licencias) o a posteriori (a través de la fiscalización). De modo que, cumplida en parte la obligación de tomar medidas tendientes a garantizar estos derechos, aún en los casos en los que las medidas no impliquen directamente la prestación de servicios por el Estado, queda siempre abierta la posibilidad de plantear judicialmente la violación de obligaciones del Estado por asegurar discriminatoriamente el derecho. Las posibilidades son más evidentes cuando el Estado presta efectivamente un servicio en forma parcial, discriminando a capas enteras de la población. Pueden subsistir, evidentemente, dificultades procesales y operativas en el planteo de casos semejantes, pero difícilmente pueda discutirse que la realización parcial o discriminatoria de una obligación positiva no resulte materia justiciable.

La CSJN ha resuelto dar plena operatividad y sin discriminaciones a la legislación que regula derechos sociales en particular, como la que asegura la asistencia integral de las personas con discapacidad, por ejemplo, o aquellas destinadas a asegurar la asistencia médica efectiva por parte del Estado Nacional y/o provincial, o a las obras sociales o prepagas. $^{57}$

No cabe duda de que la implementación de derechos sociales depende en parte de actividades de planificación, previsión presupuestaria y puesta en marcha que corresponden a los poderes políticos, siendo limitados los casos en los que el Poder Judicial puede llevar a cabo la tarea de suplir la inactividad de aquéllos. Ahora bien, uno de los sentidos de la

57 CSJN- Sanchez Norma Rosa c/ Estado Nacional y otro s/ Acción de Amparo"-S.730..XL-20-12-2005 
adopción de cláusulas constitucionales o de tratados que establecen derechos para las personas y obligaciones o compromisos para el Estado, consiste en la posibilidad de reclamo de cumplimiento de esos compromisos no como concesión graciosa, sino en tanto que programa de gobierno asumido tanto interna como internacionalmente.

Parece evidente que, en este contexto, es importante establecer mecanismos de comunicación, debate y diálogo a través de los cuales se "recuerde" a los poderes públicos los compromisos asumidos, forzándolos a incorporar dentro de las prioridades de gobierno la toma de medidas destinadas a cumplir con sus obligaciones en materia de derechos sociales.

Resulta especialmente relevante a este respecto que sea el propio Poder Judicial el que "comunique" a los poderes políticos el incumplimiento de sus obligaciones en esta materia. Cuando el poder político no cumpla con las obligaciones frente a las que es "puesto en mora" por el Poder Judicial, se enfrentará a la correspondiente responsabilidad política que derive de su actuación morosa ante su propia población y a la supletoria intervención judicial para subsanar la violación constitucional producida, por los otros poderes del Estado, por acción u omisión". 58

Al respecto, es pertinente recordar la línea argumentativa del Comité de Derechos Económicos, Sociales y Culturales, plasmada en la ya mencionada Opinión General Nro. 9 59. El Comité interpreta la obligación de adoptar medidas de orden interno para dar plena efectividad a los derechos establecidos en el PIDESC, contenida en el art. 2.1 del Pacto, a la luz de dos principios: a) la obligación de los Estados de modificar el ordenamiento jurídico interno en la medida necesaria para dar efectividad a las obligaciones dimanantes de los tratados en los que sean Parte, y b) el "derecho a un recurso efectivo, ante los tribunales nacionales competentes, que la ampare contra actos que violen sus derechos fundamentales reconocidos por la constitución o por la ley", establecido por el artículo 8 de la Declaración Universal de Derechos Humanos. Articulando ambos principios, el Comité señala que "los Estados Partes que pretendan justificar el hecho de no ofrecer ningún recurso jurídico interno frente a las violaciones de los derechos económicos, sociales y culturales tendrán que demostrar o bien que esos recursos no son "medios apropiados" según los términos del

\footnotetext{
58 CSJN-“Caso Badaro Adolfo Valentín c/ Anses s/ Reajustes varios”-B.675.XLI-08-08-2006

${ }^{59}$ Observación general № 9: La aplicación interna del Pacto http://www.escr-net.org/docs/i/428708
} 
párrafo 1 del artículo 2 del Pacto Internacional de Derechos Económicos, Sociales y Culturales, o bien que, a la vista de los demás medios utilizados, son innecesarios. Esto será difícil demostrarlo, y el Comité entiende que, en muchos casos, los demás medios utilizados puedan resultar ineficaces si no se refuerzan o complementan con recursos judiciales"

3.- A modo de referencia. Qué dice el Sistema Internacional de Derechos Humanos $\underline{\text { sobre los Desc. }}$

\section{1 El derecho a una vivienda digna}

Así receptado en el art. 14 bis de nuestra Constitución Nacional, fruto de la influencia del constitucionalismo social en nuestro derecho, se traduce también en el derecho a una vivienda adecuada que el PIDESC enumera como elemento del derecho a un adecuado nivel de vida en su art. 11.

No hay duda de que la vivienda adecuada es una de las condiciones esenciales para llevar una vida que pueda llamarse digna.

La crisis de la vivienda de décadas pasadas fue, para muchos pueblos y personas, el resultado de una despreocupación por el derecho a una vivienda digna. Un documento de las Naciones Unidas afirmó que la difícil situación económica de muchos países a principios de los 80, se reflejó en un rápido descenso de los recursos disponibles para inversiones y servicios relacionados con el campo de los asentamientos humanos. Subsidios nacionales para la vivienda, controles de alquileres y préstamos hipotecarios han estado disminuyendo constantemente.

Aún cuando existe una amplia variedad de instrumentos internacionales que abordan los diferentes aspectos del derecho a una vivienda adecuada, el párrafo 1 del artículo 11 del Pacto es la más amplia, y quizás la más importante, de todas las disposiciones pertinentes.

En opinión del Comité de Derechos Económicos, Sociales y Culturales, que analiza la cuestión en su Observación General N 4 del año 1991: 
"el derecho a la vivienda no se debe interpretar en un sentido estricto o restrictivo que lo equipare, por ejemplo, con el cobijo que resulta del mero hecho de tener un tejado por encima de la cabeza o lo considere exclusivamente como una comodidad".

Debe considerarse más bien como el derecho a vivir en seguridad, paz y dignidad en alguna parte. Y así debe ser por lo menos por dos razones. En primer lugar, el derecho a la vivienda está vinculado por entero a otros derechos humanos y a los principios fundamentales que sirven de premisas al Pacto. Así pues, "la dignidad inherente a la persona humana", de la que se dice que se derivan los derechos del Pacto, exige que el término "vivienda" se interprete en un sentido que tenga en cuenta otras diversas consideraciones, y principalmente que el derecho a la vivienda se debe garantizar a todos, sean cuales fueren sus ingresos o su acceso a recursos económicos.

En segundo lugar, la referencia que figura en el párrafo 1 del artículo 11 no se debe entender en sentido de vivienda a secas, sino de vivienda adecuada. Como han reconocido la Comisión de Asentamientos Humanos y la Estrategia Mundial de Vivienda hasta el Año 2000 en su párrafo 5:

"el concepto de "vivienda adecuada"... significa disponer de un lugar donde poderse aislar si se desea, espacio adecuado, seguridad adecuada, iluminación y ventilación adecuadas, una infraestructura básica adecuada y una situación adecuada en relación con el trabajo y los servicios básicos, todo ello a un costo razonable". ${ }^{60}$

Así pues, afirma el Comité que el concepto de adecuación es particularmente significativo en relación con el derecho a la vivienda, puesto que sirve para subrayar una serie de factores que hay que tener en cuenta al determinar si determinadas formas de vivienda se puede considerar que constituyen una "vivienda adecuada" a los efectos del Pacto. Aún cuando la adecuación viene determinada en parte por factores sociales, económicos, culturales, climatológicos, ecológicos y de otra índole, el Comité considera

\footnotetext{
60 Observación General $N^{\circ} 4$. Comité de derechos económicos, sociales y culturales Sexto Período de Sesiones. 1991. HRI/GEN/1/Rev. 7.-
} 
que, es posible identificar algunos aspectos de ese derecho que deben ser tenidos en cuenta a estos efectos en cualquier contexto determinado. Entre esos aspectos figuran los siguientes:

a) Seguridad jurídica de la tenencia. La tenencia adopta una variedad de formas, como el alquiler (público y privado), la vivienda en cooperativa, el arriendo, la ocupación por el propietario, la vivienda de emergencia y los asentamientos informales, incluida la ocupación de tierra o propiedad. Sea cual fuere el tipo de tenencia, todas las personas deben gozar de cierto grado de seguridad de tenencia que les garantice una protección legal contra el desahucio, el hostigamiento u otras amenazas.

b) Disponibilidad de servicios, materiales, facilidades e infraestructura. Una vivienda adecuada debe contener ciertos servicios indispensables para la salud, la seguridad, la comodidad y la nutrición. Todos los beneficiarios del derecho a una vivienda adecuada deberían tener acceso permanente a recursos naturales y comunes, a agua potable, a energía para la cocina, la calefacción y el alumbrado, a instalaciones sanitarias y de aseo, de almacenamiento de alimentos, de eliminación de desechos, de drenaje y a servicios de emergencia.

c) Gastos soportables. Los gastos personales o del hogar que entraña la vivienda deberían ser de un nivel que no impidiera ni comprometiera el logro y la satisfacción de otras necesidades básicas. Los Estados Partes deberían crear subsidios de vivienda para los que no pueden costearse una vivienda, así como formas y niveles de financiación que correspondan adecuadamente a las necesidades de vivienda. De conformidad con el principio de la posibilidad de costear la vivienda, se debería proteger por medios adecuados a los inquilinos contra niveles o aumentos desproporcionados de los alquileres. En las sociedades en que los materiales naturales constituyen las principales fuentes de material de construcción de vivienda, los Estados Partes deberían adoptar medidas para garantizar la disponibilidad de esos materiales.

d) Habitabilidad. Una vivienda adecuada debe ser habitable, en sentido de poder ofrecer espacio adecuado a sus ocupantes y de protegerlos del frío, la humedad, el calor, la lluvia, el viento u otras amenazas para la salud, de riesgos estructurales y de vectores de enfermedad. Debe garantizar también la seguridad física de los ocupantes. El Comité exhorta a los Estados Partes a que apliquen ampliamente los Principios de Higiene de la 
Vivienda preparados por la OMS, que consideran la vivienda como el factor ambiental que con más frecuencia está relacionado con las condiciones que favorecen las enfermedades en los análisis epidemiológicos; dicho de otro modo, que una vivienda y unas condiciones de vida inadecuadas y deficientes se asocian invariablemente a tasas de mortalidad y morbilidad más elevadas.

e) Asequibilidad. La vivienda adecuada debe ser asequible a los que tengan derecho. Debe concederse a los grupos en situación de desventaja un acceso pleno y sostenible a los recursos adecuados para conseguir una vivienda. Debería garantizarse cierto grado de consideración prioritaria en la esfera de la vivienda a los grupos desfavorecidos como las personas de edad, los niños, los incapacitados físicos, los enfermos terminales, los individuos VIH positivos, las personas con problemas médicos persistentes, los enfermos mentales, las víctimas de desastres naturales, las personas que viven en zonas en que suelen producirse desastres, y otros grupos de personas. Tanto las disposiciones como la política en materia de vivienda deben tener plenamente en cuenta las necesidades especiales de esos grupos. En muchos Estados Partes, el mayor acceso a la tierra por sectores desprovistos de tierra o empobrecidos de la sociedad, debería ser el centro del objetivo de la política. Los Estados deben asumir obligaciones apreciables destinadas a apoyar el derecho de todos a un lugar seguro para vivir con dignidad, incluido el acceso a la tierra como derecho.

f) Lugar. La vivienda adecuada debe encontrarse en un lugar que permita el acceso a las opciones de empleo, los servicios de atención de la salud, centros de atención para niños, escuelas y otros servicios sociales. Esto es particularmente cierto en ciudades grandes y zonas rurales donde los costos temporales y financieros para llegar a los lugares de trabajo y volver de ellos puede imponer exigencias excesivas en los presupuestos de las familias pobres. De manera semejante, la vivienda no debe construirse en lugares contaminados ni en la proximidad inmediata de fuentes de contaminación que amenazan el derecho a la salud de los habitantes.

g) Adecuación cultural. La manera en que se construye la vivienda, los materiales de construcción utilizados y las políticas en que se apoyan deben permitir adecuadamente la expresión de la identidad cultural y la diversidad de la vivienda. 


\section{1.1 Las violaciones al derecho a una vivienda adecuada}

La falta de hogar es quizás el síntoma más visible y más grave de la inobservancia del derecho a una vivienda adecuada.

Además, tanto las personas como las familias tienen derecho a una vivienda adecuada. En particular el disfrute de este derecho no debe estar sujeto — según el párrafo 2 del art. 2 del PIDESC - a ninguna forma de discriminación.

Pese a ello, el Relator Especial insiste en que las mujeres en todas partes afrontan mayores obstáculos para materializar su derecho a una vivienda adecuada. ${ }^{61}$

Afirma el relator que la protección del derecho de la mujer a una vivienda adecuada debe hacer que toda estrategia gire en torno a la indivisibilidad de los derechos humanos, incorporando tanto elementos civiles como políticos (por ejemplo, el derecho a la seguridad, el derecho a la participación, el derecho a la información), así como los componentes económicos, sociales y culturales del derecho a una vivienda adecuada (por ejemplo, el derecho a la alimentación, a la educación, a la tierra, al suministro de agua).

La falta de una vivienda adecuada puede hacer a las mujeres más vulnerables ante diversas formas de violencia y, a la inversa, la violencia contra las mujeres puede conducir a la violación del derecho de la mujer a una vivienda adecuada.

La legislación contra la violencia doméstica debe reconocer el nexo que le une al derecho a una vivienda adecuada e incorporar protecciones jurídicas para que las mujeres realicen este derecho, y a la vez garantizar que se ofrece a las víctimas de la violencia y los abusos domésticos una vivienda alternativa adecuada.

En la consulta de América Latina y el Caribe se señaló que las mujeres se enfrentan a una combinación de diferentes discriminaciones, por ser pobres y mujeres, lo que a menudo queda patente en el vínculo existente entre la violencia doméstica y la falta de una vivienda adecuada y la exclusión de los servicios sociales privatizados. Los participantes recalcaron que, en este contexto, a pesar de la función de los agentes privados, el Estado sigue siendo el principal responsable de la protección y la realización del derecho a una vivienda adecuada.

\footnotetext{
61 Informe presentado ante la Comisión de Derechos Humanos del Consejo Económico y Social de las Naciones Unidas durante su $61^{\circ}$ Período de Sesiones. 25 de Febrero de 2005. E/CN.4/2005/43. Párr. 4.-
} 
Afirma el relator especial de las Naciones Unidas sobre el derecho a una vivienda adecuada, Miloon Kothari ${ }^{62}$, que:

“si bien la mayoría de la población mundial vive en algún tipo de alojamiento, aproximadamente la mitad no goza de todos los derechos necesarios para que esa vivienda pueda considerarse adecuada. Según las estimaciones de las Naciones Unidas, cerca de 100 millones de personas en todo el mundo no tienen donde vivir y más de 1.000 millones no tienen una vivienda adecuada".

El Relator Especial observa con preocupación que el proceso de "aburguesamiento" de zonas urbanas deprimidas, que va acompañado de un aumento del valor de la propiedad $\mathrm{y}$ de los alquileres, hace que familias de bajos ingresos vivan en condiciones precarias e incluso que se queden sin vivienda. La existencia de los barrios marginales y los asentamientos de precaristas se debe en parte al enorme déficit de vivienda asequible en el sector estructurado. Preocupan también al Relator Especial las reducciones en los gastos de vivienda pública, las presiones en el mercado de la vivienda de alquiler y las subvenciones para vivienda y servicios comunitarios destinadas a los pobres.

La falta de protección de las personas sin vivienda y sin tierra de todo el mundo por los sistemas jurídicos se une a la tendencia que existe a penalizarlas y a intensificar la violencia contra ellas.

Pero ya se trate de cuestiones normativas, de supuestos casos de uso excesivo de la fuerza, de falta de consulta y notificación previa, o de falta de disposiciones de indemnización o de otras soluciones de vivienda, la inseguridad fundamental de llegar a quedarse sin hogar contribuye a una "cultura del miedo" con la que los pobres tienen que vivir y que sin duda atenta severamente contra la realización de este derecho fundamental.

Una manera de definir la falta de hogar es caracterizarla en sentido estricto como falta de techo, alojamiento y casa. Sin embargo, ese tipo de definiciones es insuficiente. En los países en desarrollo la definición más corriente de falta de hogar considera que el

\footnotetext{
62 Informe presentado ante la Comisión de Derechos Humanos del Consejo Económico y Social de las Naciones Unidas durante su 61 Período de Sesiones. 3 de Marzo de 2005. E/CN.4/2005/48.-
} 
elemento de marginación social forma parte de la experiencia de la persona sin hogar, poniendo de relieve que la falta de hogar implica también el hecho de no pertenecer a ningún lugar y no sólo el de no tener dónde dormir. Como se ha señalado anteriormente, la vivienda adecuada no sólo consiste en un techo y cuatro paredes sino también en un lugar para vivir en paz y con dignidad. ${ }^{63}$

El concepto de hogar a menudo se asocia con el de pertenencia, identidad y familia y el derecho a la vivienda adecuada es indivisible del respeto a los demás derechos fundamentales.

La falta de vivienda o las malas condiciones de habitabilidad de las mismas son causas de fuertes restricciones en el acceso a otros derechos tales como la salud, la educación y el trabajo.

Para impedir que haya más personas sin hogar y a la vista de las persistentes violaciones del derecho a la vivienda, es esencial que los Estados cumplan su obligación de no establecer medidas regresivas y se abstengan de reducir los parques de vivienda pública, de limitar el acceso a subsidios a la vivienda, y de restringir el acceso a medidas de amparo en las infracciones relativas al derecho a la vivienda. ${ }^{64}$

\subsubsection{Derecho a la vivienda adecuada: Estado de situación en Argentina}

Al considerar el Primer Informe presentado por el Estado Argentino, el Comité sostuvo sobre la situación de este derecho:

“.. que le preocupa hondamente el número considerable de ocupaciones ilegales de edificios, sobre todo en Buenos Aires, y las condiciones en que se llevan a cabo las correspondientes expulsiones. El Comité señala a la atención del Gobierno el texto de la Observación General $N^{\circ} 4$ sobre el derecho a una vivienda adecuada y le insta a que la política, las leyes y la práctica tomen debidamente en cuenta esa Observación General" ${ }^{\text {65 }}$.

\footnotetext{
${ }^{63}$ Idem ant. Párr. 13.-

64 Informe presentado ante la Comisión de Derechos Humanos del Consejo Económico y Social de las Naciones Unidas durante su $61^{\circ}$ Período de Sesiones. 25 de Febrero de 2005. E/CN.4/2005/43.-

65 U.N.Doc.E/C.12/1994/20 at.52 (1995), punto 237.
} 
Argentina ha incumplido además con la obligación de proveer y sistematizar la información necesaria para efectuar un adecuado diagnóstico de la realización del derecho a una vivienda adecuada.

La Observación General $N^{\circ} 1$ en su punto 3 señala que:

“... el primer paso indispensable para promover la efectividad de los derechos económicos, sociales y culturales es el diagnóstico y conocimiento de la situación existente".

En igual sentido, la Observación General $N^{0} 4$ es elocuente a este respecto, cuando en su punto 13 sostiene: "La vigilancia eficaz de la situación con respecto a la vivienda es otra obligación de efecto inmediato. Para que un Estado Parte satisfaga sus obligaciones en virtud del párrafo 1 del artículo 11, debe demostrar, entre otras cosas, que ha tomado todas las medidas que son necesarias, sea sólo o sobre la base de la cooperación internacional, para evaluar la importancia de la falta de hogares y la vivienda inadecuada dentro de su jurisdicción.

A este respecto, las Directrices generales revisadas en materia de presentación de informes adoptadas por el Comité (E/C.12/1991/1) destacan la necesidad de 'proporcionar información detallada sobre aquellos grupos de la sociedad que se encuentran en una situación vulnerable y desventajosa en materia de vivienda'. Incluyen, en particular, las personas sin hogar y sus familias, las alojadas inadecuadamente y las que no tienen acceso a instalaciones básicas, las que viven en asentamientos 'ilegales', las que están sujetas a desahucios forzados y los grupos de bajos ingresos".

En referencia a este punto, debemos citar la Observación General No 4 cuando establece:

"Todos los beneficiarios del derecho a una vivienda adecuada deben tener acceso permanente a recursos naturales y comunes, agua potable, energía para la cocina, calefacción y alumbrado, instalaciones sanitarias y de aseo, almacenamiento de alimentos, eliminación de desechos, drenaje y servicios de emergencia" 
El Estado, tiene la obligación de garantizar a todos sus habitantes, el derecho a una vivienda adecuada, sean cuales fueren sus ingresos o su acceso a recursos económicos (Observación General $N^{o}$ 4, párraf. 7) y de demostrar que, en conjunto, las medidas que se están tomando son suficientes para realizar el derecho de cada individuo en el tiempo más breve posible de conformidad con el máximo de los recursos disponibles (Observación General No 4, párraf. 14). Además, en caso de que adopte medidas de carácter retroactivo en cuanto al alcance del derecho, se requerirá la consideración más cuidadosa por parte del Comité y deberán justificarse plenamente por referencia a la totalidad de los derechos previstos en el Pacto y en el contexto del aprovechamiento pleno del máximo de los recursos de que disponga (Observación General No 3, párraf. 9).

De lo hasta aquí reseñado podemos afirmar por un lado, que los recursos que el Estado argentino se encuentra destinando para resolver el problema habitacional de sus ciudadanos resultan claramente insuficientes. En consecuencia, deberá demostrar que en conjunto, las medidas que se están tomando son suficientes para realizar el derecho de cada individuo en el tiempo más breve posible de conformidad con el máximo de los recursos disponibles, tal como lo prescribe la Observación General reseñada. Por otro, se observa un claro retroceso en lo que respecta al alcance y amplitud de goce del derecho bajo análisis. En consecuencia, el Estado deberá justificar la adopción de medidas regresivas, en referencia a los parámetros ya referidos establecidos en la Observación General № 3 .

\section{2 El derecho al disfrute del más alto nivel posible de salud}

Tal como bien refiere el Comité de Derechos Económicos Sociales y Culturales en su Observación General Nro. 14 del año 2000, la salud es un derecho humano fundamental e indispensable para el ejercicio de los demás derechos humanos. Todo ser humano tiene derecho al disfrute del más alto nivel posible de salud que le permita vivir dignamente. La efectividad del derecho a la salud se puede alcanzar mediante numerosos procedimientos complementarios, como la formulación de políticas en materia de salud, la aplicación de los programas de salud elaborados por la Organización Mundial de la Salud (OMS) o la adopción de instrumentos jurídicos concretos. 
Numerosos instrumentos de derecho internacional reconocen el derecho del ser humano a la salud. En el párrafo 1 del artículo 25 de la Declaración Universal de Derechos Humanos se afirma que "toda persona tiene derecho a un nivel de vida adecuado que le asegure, así como a su familia, la salud y en especial la alimentación, el vestido, la vivienda, la asistencia médica y los servicios sociales necesarios". El Pacto Internacional de Derechos Económicos, Sociales y Culturales contiene el artículo más exhaustivo del derecho internacional de los derechos humanos sobre el derecho a la salud. En virtud del párrafo 1 del artículo 12 del Pacto, los Estados Partes reconocen "el derecho de toda persona al disfrute del más alto nivel posible de salud física y mental", mientras que en el párrafo 2 del artículo 12 se indican, a título de ejemplo, diversas "medidas que deberán adoptar los Estados Partes a fin de asegurar la plena efectividad de este derecho".

Además, el derecho a la salud se reconoce, en particular, en el inciso iv) del apartado e) del artículo 5 de la Convención Internacional sobre la Eliminación de todas las Formas de Discriminación Racial, de 1965; en el apartado f) del párrafo 1 del artículo 11 y el artículo 12 de la Convención sobre la eliminación de todas las formas de discriminación contra la mujer, de 1979; así como en el artículo 24 de la Convención sobre los Derechos del Niño, de 1989.

Asimismo, varios instrumentos regionales de derechos humanos, como la Carta Social Europea de 1961 en su forma revisada (art. 11), la Carta Africana de Derechos Humanos y de los Pueblos, de 1981 (art. 16), y el Protocolo adicional a la Convención Americana sobre Derechos Humanos en Materia de Derechos Económicos, Sociales y Culturales, de 1988 (art. 10), también reconocen el derecho a la salud. Análogamente, el derecho a la salud ha sido proclamado por la Comisión de Derechos Humanos, así como también en la Declaración y Programa de Acción de Viena de 1993 y en otros instrumentos internacionales

El derecho a la salud está estrechamente vinculado con el ejercicio de otros derechos humanos y depende de esos derechos, que se enuncian en la Carta Internacional de Derechos, en particular el derecho a la alimentación, a la vivienda, a la dignidad humana, a la vida, a la no discriminación, a la igualdad, a no ser sometido a torturas, a la vida privada, al acceso a la información y a la libertad de asociación, reunión y circulación. 
Esos y otros derechos y libertades abordan los componentes integrales del derecho a la salud.

Al elaborar el artículo 12 del Pacto, la Tercera Comisión de la Asamblea General de las Naciones Unidas no adoptó la definición de la salud que figura en el preámbulo de la Constitución de la OMS, que concibe la salud como "un estado de completo bienestar físico, mental y social, y no solamente como ausencia de afecciones o enfermedades". Sin embargo, la referencia que en el párrafo 1 del artículo 12 del Pacto se hace al "más alto nivel posible de salud física y mental" no se limita al derecho a la atención de la salud. Por el contrario, el historial de la elaboración y la redacción expresa del párrafo 2 del artículo 12 reconoce que el derecho a la salud abarca una amplia gama de factores socioeconómicos que promueven las condiciones merced a las cuales las personas pueden llevar una vida sana, y hace ese derecho extensivo a los factores determinantes básicos de la salud, como la alimentación y la nutrición, la vivienda, el acceso a agua limpia potable y a condiciones sanitarias adecuadas, condiciones de trabajo seguras y sanas y un medio ambiente sano.

Por ello, no cabe duda en afirmar que para millones de personas en todo el mundo el pleno disfrute del derecho a la salud continúa siendo un objetivo remoto. Es más, en muchos casos, sobre todo por lo que respecta a las personas que viven en la pobreza, ese objetivo es cada vez más remoto.

El Comité interpreta el derecho a la salud, definido en el apartado 1 del artículo 12, como un derecho inclusivo que no sólo abarca la atención de salud oportuna y apropiada sino también los principales factores determinantes de la salud, como el acceso al agua limpia potable y a condiciones sanitarias adecuadas, el suministro adecuado de alimentos sanos, una nutrición adecuada, una vivienda adecuada, condiciones sanas en el trabajo y el medio ambiente, y acceso a la educación e información sobre cuestiones relacionadas con la salud, incluida la salud sexual y reproductiva. Otro aspecto importante es la participación de la población en todo el proceso de adopción de decisiones sobre las cuestiones relacionadas con la salud en los planos comunitario, nacional e internacional.

El derecho a la salud en todas sus formas y a todos los niveles abarca los siguientes elementos esenciales e interrelacionados, cuya aplicación dependerá de las condiciones prevalecientes en un determinado Estado Parte: 
a) Disponibilidad. Cada Estado Parte deberá contar con un número suficiente de establecimientos, bienes y servicios públicos de salud y centros de atención de la salud, así como de programas. La naturaleza precisa de los establecimientos, bienes y servicios dependerá de diversos factores, en particular el nivel de desarrollo del Estado Parte. Con todo, esos servicios incluirán los factores determinantes básicos de la salud, como agua limpia potable y condiciones sanitarias adecuadas, hospitales, clínicas y demás establecimientos relacionados con la salud, personal médico y profesional capacitado y bien remunerado habida cuenta de las condiciones que existen en el país, así como los medicamentos esenciales definidos en el Programa de Acción sobre medicamentos esenciales de la OMS .

b) Accesibilidad. Los establecimientos, bienes y servicios de salud deben ser accesibles a todos, sin discriminación alguna, dentro de la jurisdicción del Estado Parte. La accesibilidad presenta cuatro dimensiones superpuestas:

i) No discriminación: los establecimientos, bienes y servicios de salud deben ser accesibles, de hecho y de derecho, a los sectores más vulnerables y marginados de la población, sin discriminación alguna por cualquiera de los motivos prohibidos .

ii) Accesibilidad física: los establecimientos, bienes y servicios de salud deberán estar al alcance geográfico de todos los sectores de la población, en especial los grupos vulnerables o marginados, como las minorías étnicas y poblaciones indígenas, las mujeres, los niños, los adolescentes, las personas mayores, las personas con discapacidades y las personas con VIH/SIDA. La accesibilidad también implica que los servicios médicos y los factores determinantes básicos de la salud, como el agua limpia potable y los servicios sanitarios adecuados, se encuentran a una distancia geográfica razonable, incluso en lo que se refiere a las zonas rurales. Además, la accesibilidad comprende el acceso adecuado a los edificios para las personas con discapacidades.

iii) Accesibilidad económica (asequibilidad): los establecimientos, bienes y servicios de salud deberán estar al alcance de todos. Los pagos por servicios de atención de la salud y servicios relacionados con los factores determinantes básicos de la salud deberán basarse en el principio de la equidad, a fin de asegurar que esos servicios, sean públicos o privados, estén al alcance de todos, incluidos los grupos socialmente desfavorecidos. La 
equidad exige que sobre los hogares más pobres no recaiga una carga desproporcionada, en lo que se refiere a los gastos de salud, en comparación con los hogares más ricos.

iv) Acceso a la información: ese acceso comprende el derecho de solicitar, recibir y difundir información e ideas acerca de las cuestiones relacionadas con la salud. Con todo, el acceso a la información no debe menoscabar el derecho de que los datos personales relativos a la salud sean tratados con confidencialidad.

c) Aceptabilidad. Todos los establecimientos, bienes y servicios de salud deberán ser respetuosos de la ética médica y culturalmente apropiados, es decir respetuosos de la cultura de las personas, las minorías, los pueblos y las comunidades, a la par que sensibles a los requisitos del género y el ciclo de vida, y deberán estar concebidos para respetar la confidencialidad y mejorar el estado de salud de las personas de que se trate.

d) Calidad. Además de aceptables desde el punto de vista cultural, los establecimientos, bienes y servicios de salud deberán ser también apropiados desde el punto de vista científico y médico y ser de buena calidad. Ello requiere, entre otras cosas, personal médico capacitado, medicamentos y equipo hospitalario científicamente aprobados y en buen estado, agua limpia potable y condiciones sanitarias adecuadas.

\subsubsection{No discriminación e igualdad de trato}

En virtud de lo dispuesto en el párrafo 2 del artículo 2 y en el artículo 3, el Pacto prohíbe toda discriminación en lo referente al acceso a la atención de la salud y los factores determinantes básicos de la salud, así como a los medios y derechos para conseguirlo, por motivos de raza, color, sexo, idioma, religión, opinión política o de otra índole, origen nacional o posición social, situación económica, lugar de nacimiento, impedimentos físicos o mentales, estado de salud (incluidos el VIH/SIDA), orientación sexual y situación política, social o de otra índole que tengan por objeto o por resultado la invalidación o el menoscabo de la igualdad de goce o el ejercicio del derecho a la salud. El Comité señala que se pueden aplicar muchas medidas, como las relacionadas con la mayoría de las estrategias y los programas destinados a eliminar la discriminación relacionada con la salud, con consecuencias financieras mínimas merced a la promulgación, modificación o revocación de leyes o a la difusión de información. El Comité recuerda el párrafo 12 de la observación general $N^{0} 3$ en el que se afirma que incluso en situaciones de limitaciones 
graves de recursos es preciso proteger a los miembros vulnerables de la sociedad mediante la aprobación de programas especiales de relativo bajo costo.

En cuanto al derecho a la salud, es preciso hacer hincapié en la igualdad de acceso a la atención de la salud y a los servicios de salud. Los Estados tienen la obligación especial de proporcionar seguro médico y los centros de atención de la salud necesarios a quienes carezcan de medios suficientes, y, al garantizar la atención de la salud y proporcionar servicios de salud, impedir toda discriminación basada en motivos internacionalmente prohibidos, en especial por lo que respecta a las obligaciones fundamentales del derecho a la salud. Una asignación inadecuada de recursos para la salud puede dar lugar a una discriminación que tal vez no sea manifiesta. Por ejemplo, las inversiones no deben favorecer desproporcionadamente a los servicios curativos caros que suelen ser accesibles únicamente a una pequeña fracción privilegiada de la población, en detrimento de la atención primaria y preventiva de salud en beneficio de una parte mayor de la población.

\subsubsection{La perspectiva de género}

El Comité recomienda que los Estados incorporen la perspectiva de género en sus políticas, planificación, programas e investigaciones en materia de salud a fin de promover mejor la salud de la mujer y el hombre. Un enfoque basado en la perspectiva de género reconoce que los factores biológicos y socioculturales ejercen una influencia importante en la salud del hombre y la mujer. La desagregación, según el sexo, de los datos socioeconómicos y los datos relativos a la salud es indispensable para determinar y subsanar las desigualdades en lo referente a la salud.

\subsubsection{La mujer y el derecho a la salud}

Para suprimir la discriminación contra la mujer es preciso elaborar y aplicar una amplia estrategia nacional con miras a la promoción del derecho a la salud de la mujer a lo largo de toda su vida. Esa estrategia debe prever en particular las intervenciones con miras a la prevención y el tratamiento de las enfermedades que afectan a la mujer, así como políticas encaminadas a proporcionar a la mujer acceso a una gama completa de atenciones de la salud de alta calidad y al alcance de ella, incluidos los servicios en materia sexual y reproductiva. Un objetivo importante deberá consistir en la reducción de los riesgos que 
afectan a la salud de la mujer, en particular la reducción de las tasas de mortalidad materna y la protección de la mujer contra la violencia en el hogar. El ejercicio del derecho de la mujer a la salud requiere que se supriman todas las barreras que se oponen al acceso de la mujer a los servicios de salud, educación e información, en particular en la esfera de la salud sexual y reproductiva. También es importante adoptar medidas preventivas, promocionales y correctivas para proteger a la mujer contra las prácticas y normas culturales tradicionales perniciosas que le deniegan sus derechos genésicos.

\subsubsection{Los niños y adolescentes}

En el apartado a) del párrafo 2 del artículo 12 se pone de manifiesto la necesidad de adoptar medidas para reducir la mortinatalidad y la mortalidad infantil y promover el sano desarrollo de los niños. En los ulteriores instrumentos internacionales de derechos humanos se reconoce que los niños y los adolescentes tienen derecho al disfrute del más alto nivel posible de salud y al acceso a centros de tratamiento de enfermedades. En la Convención sobre los Derechos del Niño se exhorta a los Estados a que garanticen el acceso a los servicios esenciales de salud para el niño y su familia, incluida la atención anterior y posterior al parto de la madre. La Convención vincula esos objetivos con el acceso a la información, respetuosa del niño, sobre prevención y fomento de la salud y la prestación de ayuda a las familias y comunidades para poner en práctica esas medidas. La aplicación del principio de no discriminación requiere que tanto las niñas como los niños tengan igual acceso a una alimentación adecuada, un entorno seguro y servicios de salud física y mental. Es preciso adoptar medidas eficaces y apropiadas para dar al traste con las perniciosas prácticas tradicionales que afectan a la salud de los niños, en especial de las niñas, entre las que figuran el matrimonio precoz, las mutilaciones sexuales femeninas y la alimentación y el cuidado preferentes de los niños varones. Es preciso dar a los niños con discapacidades la oportunidad de disfrutar de una vida satisfactoria y decente y participar en las actividades de su comunidad.

Los Estados Partes deben proporcionar a los adolescentes un entorno seguro y propicio que les permita participar en la adopción de decisiones que afectan a su salud, adquirir experiencia, tener acceso a la información adecuada, recibir consejos y negociar sobre las cuestiones que afectan a su salud. El ejercicio del derecho a la salud de los 
adolescentes depende de una atención respetuosa de la salud de los jóvenes que tiene en cuenta la confidencialidad y la vida privada y prevé el establecimiento de servicios adecuados de salud sexual y reproductiva.

La consideración primordial en todos los programas y políticas con miras a garantizar el derecho a la salud del niño y el adolescente será el interés superior del niño y el adolescente.

\subsubsection{Obligaciones legales}

Al igual que todos los derechos humanos, el derecho a la salud impone tres tipos o niveles de obligaciones a los Estados Partes: la obligación de respetar, proteger y cumplir. A su vez, la obligación de cumplir comprende la obligación de facilitar, proporcionar y promover. La obligación de respetar exige que los Estados se abstengan de injerirse directa o indirectamente en el disfrute del derecho a la salud. La obligación de proteger requiere que los Estados adopten medidas para impedir que terceros interfieran en la aplicación de las garantías prevista en el artículo 12. Por último, la obligación de cumplir requiere que los Estados adopten medidas apropiadas de carácter legislativo, administrativo, presupuestario, judicial o de otra índole para dar plena efectividad al derecho a la salud.

En particular, los Estados tienen la obligación de respetar el derecho a la salud, en particular absteniéndose de denegar o limitar el acceso igual de todas las personas, incluidos, los presos o detenidos, los representantes de las minorías, los solicitantes de asilo o los inmigrantes ilegales, a los servicios de salud preventivos, curativos y paliativos; abstenerse de imponer prácticas discriminatorias como política de Estado; y abstenerse de imponer prácticas discriminatorias en relación con el estado de salud y las necesidades de la mujer. Además, las obligaciones de respetar incluyen la obligación del Estado de abstenerse de prohibir o impedir los cuidados preventivos, las prácticas curativas y las medicinas tradicionales, comercializar medicamentos peligrosos y aplicar tratamientos médicos coercitivos, salvo en casos excepcionales para el tratamiento de enfermedades mentales o la prevención de enfermedades transmisibles y la lucha contra ellas.

Esas excepciones deberán estar sujetas a condiciones específicas y restrictivas, respetando las mejores prácticas y las normas internacionales aplicables, en particular los Principios de las Naciones Unidas para la protección de los enfermos mentales y para el 
mejoramiento de la atención de la salud mental. Asimismo, los Estados deben abstenerse de limitar el acceso a los anticonceptivos $\mathrm{u}$ otro medios de mantener la salud sexual y genésica, censurar, ocultar o desvirtuar intencionalmente la información relacionada con la salud, incluida la educación sexual y la información al respecto, así como impedir la participación del pueblo en los asuntos relacionados con la salud. Los Estados deben abstenerse asimismo de contaminar ilegalmente la atmósfera, el agua y la tierra, por ejemplo mediante los desechos industriales de las instalaciones propiedad del Estado, utilizar o ensayar armas nucleares, biológicas o químicas si, como resultado de esos ensayos, se liberan sustancias nocivas para la salud del ser humano, o limitar el acceso a los servicios de salud como medida punitiva, por ejemplo durante conflictos armados, en violación del derecho internacional humanitario.

Las obligaciones de proteger incluyen, entre otras, las obligaciones de los Estados de adoptar leyes u otras medidas para velar por el acceso igual a la atención de la salud y los servicios relacionados con la salud proporcionados por terceros; velar por que la privatización del sector de la salud no represente una amenaza para la disponibilidad, accesibilidad, aceptabilidad y calidad de los servicios de atención de la salud; controlar la comercialización de equipo médico y medicamentos por terceros, y asegurar que los facultativos y otros profesionales de la salud reúnan las condiciones necesarias de educación, experiencia y deontología. Los Estados también tienen la obligación de velar por que las prácticas sociales o tradicionales nocivas no afecten al acceso a la atención anterior y posterior al parto ni a la planificación de la familia; impedir que terceros induzcan a la mujer a someterse a prácticas tradicionales, por ejemplo a la mutilación de los órganos genitales femeninos; y de adoptar medidas para proteger a todos los grupos vulnerables o marginados de la sociedad, en particular las mujeres, los niños, los adolescentes y las personas mayores, teniendo en cuenta los actos de violencia desde la perspectiva de género. Los Estados deben velar asimismo por que terceros no limiten el acceso de las personas a la información y los servicios relacionados con la salud.

La obligación de cumplir requiere, en particular, que los Estados Partes reconozcan suficientemente el derecho a la salud en sus sistemas políticos y ordenamientos jurídicos nacionales, de preferencia mediante la aplicación de leyes, y adopten una política nacional de salud acompañada de un plan detallado para el ejercicio del derecho a la salud. Los 
Estados deben garantizar la atención de la salud, en particular estableciendo programas de inmunización contra las principales enfermedades infecciosas, y velar por el acceso igual de todos a los factores determinantes básicos de la salud, como alimentos nutritivos sanos y agua potable, servicios básicos de saneamiento y vivienda y condiciones de vida adecuadas. La infraestructura de la sanidad pública debe proporcionar servicios de salud sexual y genésica, incluida la maternidad segura, sobre todo en las zonas rurales. Los Estados tienen que velar por la apropiada formación de facultativos y demás personal médico, la existencia de un número suficiente de hospitales, clínicas y otros centros de salud, así como por la promoción y el apoyo a la creación de instituciones que prestan asesoramiento y servicios de salud mental, teniendo debidamente en cuenta la distribución equitativa a lo largo del país. Otras obligaciones incluyen el establecimiento de un sistema de seguro de salud público, privado o mixto que sea asequible a todos, el fomento de las investigaciones médicas y la educación en materia de salud, así como la organización de campañas de información, en particular por lo que se refiere al VIH/SIDA, la salud sexual y genésica, las prácticas tradicionales, la violencia en el hogar, y el uso indebido de alcohol, tabaco, estupefacientes y otras sustancias nocivas. Los Estados también tienen la obligación de adoptar medidas contra los peligros que para la salud representan la contaminación del medio ambiente y las enfermedades profesionales, así como también contra cualquier otra amenaza que se determine mediante datos epidemiológicos. Con tal fin, los Estados deben formular y aplicar políticas nacionales con miras a reducir y suprimir la contaminación del aire, el agua y el suelo, incluida la contaminación causada por metales pesados tales como el plomo procedente de la gasolina. Asimismo, los Estados Partes deben formular, aplicar y revisar periódicamente una política nacional coherente destinada a reducir al mínimo los riesgos de accidentes laborales y enfermedades profesionales, así como formular una política nacional coherente en materia de seguridad en el empleo y servicios de salud.

La obligación de cumplir (facilitar) requiere en particular que los Estados adopten medidas positivas que permitan y ayuden a los particulares y las comunidades disfrutar del derecho a la salud. Los Estados Partes también tienen la obligación de cumplir (facilitar) un derecho específico enunciado en el Pacto en los casos en que los particulares o los grupos no están en condiciones, por razones ajenas a su voluntad, de ejercer por sí mismos ese derecho con ayuda de los medios a su disposición. 
La obligación de cumplir (promover) el derecho a la salud requiere que los Estados emprendan actividades para promover, mantener y restablecer la salud de la población. Entre esas obligaciones figuran las siguientes: i) fomentar el reconocimiento de los factores que contribuyen al logro resultados positivos en materia de salud, por ejemplo la realización de investigaciones y el suministro de información; ii) velar por que los servicios de salud sean apropiados desde el punto de vista cultural y el personal sanitario sea formado de manera que reconozca y responda a las necesidades concretas de los grupos vulnerables o marginados; iii) velar por que el Estado cumpla sus obligaciones en lo referente a la difusión de información apropiada acerca de la forma de vivir y la alimentación sanas, así como acerca de las prácticas tradicionales nocivas y la disponibilidad de servicios; iv) apoyar a las personas a adoptar, con conocimiento de causa, decisiones por lo que respecta a su salud.

\subsubsection{Obligaciones básicas}

En la observación general No 3, el Comité confirma que los Estados Partes tienen la obligación fundamental de asegurar como mínimo la satisfacción de niveles esenciales de cada uno de los derechos enunciados en el Pacto, incluida la atención primaria básica de la salud. Considerada conjuntamente con instrumentos más recientes, como el Programa de Acción de la Conferencia Internacional sobre Población y Desarrollo, la Declaración de Alma-Ata ofrece una orientación inequívoca en cuanto a las obligaciones básicas dimanantes del artículo 12. Por consiguiente, el Comité considera que entre esas obligaciones básicas figuran, como mínimo, las siguientes:

a) Garantizar el derecho de acceso a los centros, bienes y servicios de salud sobre una base no discriminatoria, en especial por lo que respecta a los grupos vulnerables o marginados;

b) Asegurar el acceso a una alimentación esencial mínima que sea nutritiva, adecuada y segura y garantice que nadie padezca hambre;

c) Garantizar el acceso a un hogar, una vivienda y unas condiciones sanitarias básicos, así como a un suministro adecuado de agua limpia potable;

d) Facilitar medicamentos esenciales, según las definiciones periódicas que figuran en el Programa de Acción sobre Medicamentos Esenciales de la OMS; 
e) Velar por una distribución equitativa de todas las instalaciones, bienes y servicios de salud;

f) Adoptar y aplicar, sobre la base de las pruebas epidemiológicas, una estrategia y un plan de acción nacionales de salud pública para hacer frente a las preocupaciones en materia de salud de toda la población; la estrategia y el plan de acción deberán ser elaborados, y periódicamente revisados, sobre la base de un proceso participativo y transparente; esa estrategia y ese plan deberán prever métodos, como el derecho a indicadores y bases de referencia de la salud que permitan vigilar estrechamente los progresos realizados; el proceso mediante el cual se concibe la estrategia y el plan de acción, así como el contenido de ambos, deberá prestar especial atención a todos los grupos vulnerables o marginados.

El Comité confirma asimismo que entre las obligaciones de prioridad comparables figuran las siguientes:

a) Velar por la atención de la salud genésica, materna (prenatal y postnatal) e infantil;

b) Proporcionar inmunización contra las principales enfermedades infecciosas que tienen lugar en la comunidad;

c) Adoptar medidas para prevenir, tratar y combatir las enfermedades epidémicas y endémicas;

d) Impartir educación y proporcionar acceso a la información relativa a los principales problemas de salud en la comunidad, con inclusión de los métodos para prevenir y combatir esas enfermedades;

e) Proporcionar capacitación adecuada al personal del sector de la salud, incluida la educación en materia de salud y derechos humanos.

3.3 El derecho a una alimentación adecuada

El derecho a una alimentación adecuada está reconocido en diversos instrumentos internacionales. Sin embargo es el PIDESC el que trata el derecho de una manera más extensa. 
En el párrafo 1 del art. 11 del Pacto los Estados Parte reconocen “...el derecho de toda persona a un nivel adecuado de vida para sí y su familia, incluso alimentación, vestido, y vivienda adecuados..." y en el párrafo 2 del mismo artículo reconocen que posiblemente deberán adoptarse medidas más inmediatas y urgentes para garantizar "el derecho fundamental de toda persona de estar protegida contra el hambre" y la malnutrición.

No hay dudas de que el derecho a una alimentación adecuada es de importancia fundamental para el disfrute de todos los demás derechos.

El Comité de derechos económicos, sociales y culturales analizó la cuestión durante su vigésimo período de sesiones en el año 1999 y como correlato de la discusión alcanzada emitió la Observación General $N^{\circ} 12$ interpretando los alcances del derecho que pueden vislumbrarse confusos, a la luz de su desarrollo normativo, dado que se inserta como elemento del derecho a un nivel de vida adecuado.

En este marco interpretativo otorgamos al nivel de vida adecuado el carácter de un verdadero principio rector en la materia. Queda ahora delinear los ribetes del derecho a la alimentación como un derecho con peso propio, más allá de su ubicación normativa.

"El Comité afirma que el derecho a una alimentación adecuada está inseparablemente vinculado a la dignidad inherente de la persona humana y es indispensable para el disfrute de otros derechos humanos consagrados en la Carta Internacional de Derechos Humanos. Es también inseparable de la justicia social pues requiere la adopción de políticas económicas, ambientales y sociales adecuadas, en los planos nacional e internacional, orientadas a la erradicación de la pobreza y al disfrute de todos los derechos humanos por todos"66

Además enfatiza que las raíces del problema del hambre y la malnutrición no están en la falta de alimento sino en la falta de acceso a los alimentos disponibles, por parte de grandes segmentos de la población, entre otras razones, a causa de la pobreza. ${ }^{67}$

Continúa definiendo el Comité que el derecho a la alimentación adecuada se ejerce cuando todo hombre, mujer o niño, ya sea solo o en común con otros, tiene acceso físico y económico, en todo momento, a la alimentación adecuada o a los medios para obtenerla.

\footnotetext{
${ }^{66}$ Comité de Derechos económicos, sociales y culturales. Observación General Nㅜ⒓ 20 Período de Sesiones. 1999. Párr. 4.-

67 Observación General Nº 12 cit. Párr. 5.-
} 
Este derecho no debe interpretarse en forma estrecha o restrictiva asimilándolo a un conjunto de calorías, proteínas y otros elementos nutritivos concretos.

La Observación General en análisis, prosigue definiendo dos términos esenciales en cuanto a la vigencia de este derecho: adecuación y sostenibilidad de la disponibilidad de alimentos y del acceso a éstos.

El concepto de adecuación sirve para poner de relieve una serie de factores que deben tenerse en cuenta al determinar si puede considerarse que ciertas formas de alimentos o regímenes de alimentación a las que se tiene acceso son las más adecuadas en determinadas circunstancias a los fines de lo dispuesto en el art. 11 del Pacto.

A la vez, la noción de sostenibilidad está íntimamente vinculada al concepto de alimentación adecuada o de seguridad alimentaria, que entraña la posibilidad de acceso a los alimentos por parte de las generaciones presentes y futuras.

El significado preciso de "adecuación" viene determinado en buena medida por las condiciones sociales, económicas, culturales, climáticas, ecológicas y de otro tipo imperantes en el momento, mientras que el de "sostenibilidad" entraña el concepto de disponibilidad y accesibilidad a largo plazo.

El Comité considera que integran el contenido básico del derecho a una alimentación adecuada:

a) la disponibilidad de alimentos en cantidad y calidad suficientes para satisfacer las necesidades alimentarias de los individuos, sin sustancias nocivas, y aceptables para una cultura determinada;

b) la accesibilidad de esos alimentos en formas que sean sostenibles y que no dificulten el goce de otros derechos humanos.

Pueden advertirse dos características propias de los derechos económicos, sociales y culturales. El carácter situacional de las necesidades y de los derechos que garantizan su satisfacción, circunstancia que queda plasmada en el hecho de que la disponibilidad de alimentos debe ser aceptable para una cultura determinada; y la indivisibilidad e interdependencia de todos los derechos humanos, en virtud de la cual la accesibilidad de los alimentos no debe dificultar el goce de otros derechos.

En palabras del Comité, se entiende por necesidades alimentarias el régimen de alimentación en conjunto que aporta una combinación de productos nutritivos para el 
crecimiento físico y mental, el desarrollo y el mantenimiento y la actividad física que sea suficiente para satisfacer las necesidades fisiológicas humanas en todas las etapas del ciclo vital y según el sexo y la ocupación. ${ }^{68}$

A la vez será preciso garantizar que los cambios en la disponibilidad y acceso a los alimentos mínimos no afecten negativamente a la composición e ingesta de alimentos.

Por disponibilidad entiende el Comité "las posibilidades que tiene el individuo de alimentarse ya sea directamente, explotando la tierra productiva $\mathrm{u}$ otras fuentes naturales de alimentos, o mediante sistemas de distribución, elaboración y comercialización que funciones adecuadamente y que puedan trasladar los alimentos desde el lugar de producción a donde sea necesario según la demanda.

Finalmente la accesibilidad comprende la accesibilidad económica y física:

La accesibilidad económica implica que los costos financieros asociados con la adquisición de los alimentos necesarios para un régimen de alimentación adecuado, deben estar a un nivel tal que no se vean amenazadas o en peligro la provisión y la satisfacción de otras necesidades básicas. Los grupos socialmente vulnerables pueden requerir la atención de programas especiales, a tal efecto.

La accesibilidad fisica implica que la alimentación adecuada debe ser accesible a todos, incluidos los individuos físicamente vulnerables. Será necesario conceder prioridad con respecto a la accesibilidad de los alimentos a las personas integrantes de los grupos más desfavorecidos de la sociedad.

\subsubsection{Obligaciones, violaciones y responsabilidades}

Como en el caso de los demás derechos económicos, sociales y culturales la principal obligación del Estado en torno al derecho a una alimentación adecuada consiste en adoptar medidas para lograr progresivamente su pleno ejercicio.

Sin embargo, no puede dejarse de lado el carácter urgente y vital de la necesidad tutelada. Cada Estado Parte en el Pacto se compromete a adoptar medidas para garantizar que toda persona que se encuentre bajo su jurisdicción tenga acceso al mínimo de alimentos

\footnotetext{
68 Observación General Nº 12 cit. Párr. 9.-
} 
esenciales, suficientes, inocuos y nutritivamente adecuados para protegerla contra el hambre.

A la vez, cuando un individuo o un grupo sea incapaz por razones que escapen a su control, de disfrutar del derecho a una alimentación adecuada por los medios a su alcance, los Estados tienen la obligación de realizar (hacer efectivo) ese derecho directamente. ${ }^{69}$

Interpreta el Comité en la Observación General $N^{\circ} 12$ que el Pacto se viola cuando un Estado no garantiza la satisfacción de, al menos, el nivel mínimo esencial necesario para estar protegido contra el hambre. Al determinar qué medidas u omisiones constituyen una violación del derecho a la alimentación es importante distinguir entre la falta de capacidad y la falta de voluntad de un Estado para cumplir sus obligaciones. En el caso de que un Estado parte aduzca que la limitación de sus recursos le impiden facilitar el acceso a la alimentación a aquellas personas que no son capaces de obtenerla por si mismas, el Estado ha de demostrar que ha hecho todos los esfuerzos posibles por utilizar todos los recursos de que dispone, con el fin de cumplir con carácter prioritario con esas obligaciones mínimas.

El Estado que aduzca que es incapaz de cumplir esta obligación por razones que están fuera de su control (como la emergencia, por ejemplo) tiene, por tanto, la obligación de probar que ello es cierto y que no ha logrado recabar apoyo internacional para garantizar la disponibilidad y accesibilidad de los alimentos necesarios.

Entre ellos cabe señalar: derogar o suspender oficialmente la legislación necesaria para seguir disfrutando el derecho a la alimentación; negar el acceso a los alimentos a determinados individuos o grupos, tanto si la discriminación se basa en la legislación como si es activa; impedir el acceso a la ayuda alimentaria de carácter humanitario en los conflictos internos o en otras situaciones de emergencia; adoptar legislación o políticas que sean manifiestamente incompatibles con obligaciones jurídicas anteriores relativas al derecho a la alimentación; y no controlar las actividades de individuos o grupos para evitar que violen el derecho a la alimentación de otras personas; o, cuando es el Estado, no tener en cuenta sus obligaciones jurídicas internacionales relativas al derecho a la alimentación al concertar acuerdos con otros Estados o con organizaciones internacionales.

\footnotetext{
${ }^{69}$ Observación General № 12 cit. Párr. 15.-
} 
Por otra parte, toda discriminación en el acceso a los alimentos, así como a los medios y derechos para obtenerlos, por motivos de raza, color, sexo, idioma, edad, religión, opinión política, origen nacional o social, posición económica o cualquier otra condición social, con el fin o efecto de anular y obstaculizar la igualdad en el disfrute de los derechos económicos, sociales y culturales constituye una violación al Pacto.

Asimismo, interpreta el Comité que las violaciones del derecho a una alimentación adecuada pueden producirse por actos realizados directamente por los Estados o por otras entidades insuficientemente reguladas por los Estados.

En ambos casos, los Estados parte son los últimos responsables del cumplimiento o incumplimiento- del Pacto.

Tal como lo reconoce el Comité de derechos económicos, sociales y culturales, los medios más adecuados para aplicar el derecho a una alimentación adecuada variarán inevitablemente y de un modo considerable de un Estado parte a otro.

Cada Estado tiene un margen de elección para aplicar las políticas que considere apropiadas a los fines de garantizar el derecho a la alimentación de sus habitantes, pero es un deber surgente del Pacto adoptar las medidas que sean necesarias para garantizar que todas las personas queden libres del hambre.

Como se ha dicho ya, el Pacto no determina medios taxativos a los fines de efectivizar los derechos que reconoce, pero impone metas claras y entre ellas, la erradicación del hambre en los Estados parte aparece como horizonte inmediato.

Dar acabado cumplimiento a la norma internacional exige aprobar una estrategia nacional que garantice la seguridad alimentaria y de nutrición para todos. La estrategia debe basarse en una determinación sistemática de las políticas pertinentes en cada situación y contexto derivadas del contenido normativo del derecho a una alimentación adecuada. ${ }^{70}$

Y sobre todo, la estrategia debe prestar una especial atención a la necesidad de prevenir la discriminación en el acceso a los alimentos o a los recursos destinados a los alimentos.

3.3.2. Las Directrices internacionales voluntarias sobre el derecho a la alimentación.

70 Observación General № 12 cit. Párr. 22.- 
Se trata de un conjunto de directrices aceptadas a nivel internacional para promover la realización progresiva del derecho a una alimentación adecuada en el contexto de la seguridad alimentaria nacional.

La iniciativa de preparar estas directrices se originó en los compromisos contraídos por los propios gobiernos en las dos Cumbres Mundiales sobre la alimentación adecuada (1996 у 2002)

Finalmente, en Noviembre de 2004 el Consejo de la FAO aprobó las Directrices Voluntarias que fueron refrendadas por todos los gobiernos.

Tal como destaca el relator especial en la materia en su informe $2005^{71}$ se trata de un paso importante porque, al aprobarlas, los gobiernos han confirmado su profundo compromiso con el derecho a una alimentación adecuada y han llegado a un entendimiento a nivel internacional, sobre el derecho a la alimentación.

"La FAO ha celebrado ese empeño que ha calificado de 'hito en el compromiso para con los derechos humanos', ya que significa la aceptación universal y proporciona un instrumento práctico que 'permitirá a los pobres y hambrientos' reclamar sus derechos"

La trascendencia de las directrices radica en el establecimiento de una definición aceptada internacionalmente del derecho a la alimentación, próxima a la adoptada por el Comité de derechos económicos, sociales y culturales ya citada y que establece la índole de las obligaciones en estos términos:

“... Los Estados parte en el PIDESC tienen la obligación de respetar, promover y proteger el derecho a una alimentación adecuada, así como de tomar las medidas oportunas para lograr progresivamente su plena realización. Los Estados parte deberían respetar el acceso existente a una alimentación adecuada absteniéndose de adoptar medidas de ningún tipo que tengan por resultado impedir ese acceso y deberían proteger el derecho de toda persona a una alimentación adecuada

\footnotetext{
${ }^{71} \mathrm{E} / \mathrm{CN} .4 / 2005 / 47 .-$

72 Ver http://www.fao.org.newsroom/en/news/2004/51653/index.html
} 
adoptando medidas para velar porque las empresas o los particulares no priven a las personas de su acceso a una alimentación adecuada...." (Informe citado Párr. 31).-

A la vez, las directrices resultan un hito porque reconocen la dimensión internacional del derecho a la alimentación abordando por ejemplo las cuestiones del comercio internacional, la ayuda alimentaría y los embargos, circunstancias que exceden el ámbito de la presente investigación.

De igual modo, ponen de manifiesto que el derecho a la alimentación se puede incorporar a las estrategias e instituciones de gobierno así como a las estrategias de reducción de la pobreza, en especial respecto de los grupos vulnerables de la sociedad (Directriz 8.3).

Las directrices voluntarias también invitan a los Estados a establecer mecanismos para mejorar el acceso a la justicia en relación al derecho a la alimentación. (Directriz 7).

De lo brevemente expuesto puede inducirse que las Directrices Voluntarias pueden repercutir positivamente en la lucha a favor del derecho a la alimentación. Sin embargo, es esencial que se aprueben como instrumentos prácticos para guiar las políticas y los programas públicos de manera que influyan realmente en el hambre y la inseguridad alimentaria a nivel mundial.

\section{VI.- Observación del fenómeno descripto}

\section{1.- Relaciones de fuerza. Un caso}

Se ha referido a lo largo de la presente, cómo el campo jurídico se encuentra determinado tanto por la lógica interna de las obras jurídicas que delimitan en cada momento el espacio de lo posible, como por las relaciones de fuerza especificas que le confieren su estructura, lo que en términos Bourdiano aparece definido como la Doxa y la Heterodoxia respectivamente, esto ha permitido analizar la relativa autonomía del campo 
jurídico en el tema que nos ocupa, y en expresa referencia a la exigibilidad y justiciabilidad de los Desc.

Así, lo expuesto ha insumido un exhaustivo análisis de la génesis de los Desc. para, en comparación con el nacimiento de los Derechos Civiles y Políticos, poder comprender en gran medida las causas de su actual exigibilidad y vigencia, la aparición del derecho y las justificaciones de las llamadas cláusulas operativas y programáticas, en razón de a quienes protegían unos y otros derechos. Desarrollado lo expuesto, y efectuado un análisis de la situación actual de varios derechos considerados primordiales en el ámbito de los Desc., se realizará ahora al análisis de un caso concreto en donde se puedan ver reflejadas las relaciones de fuerza entre grupos sociales, desigualmente investidos de capitales rentables en el campo, donde se juegan situaciones de poder, y agentes que persiguen intereses específicos y no específicos.

Tomando un caso concreto y representativo, se acorta el cuadro empírico en estudio, resultando así observable el fenómeno, y a su vez, representativo de muchos otros campos observables. De esta forma, el caso concreto motivo de análisis, muestra reflejado todo lo expuesto en las etapas anteriores (actores involucrados, intereses, condicionamientos, etc)

Mediante dicha estrategia se procura efectuar un aporte al conocimiento en el desarrollo del tema en estudio, comprobando las conclusiones en un caso de confrontación concreto y representativo del objeto de análisis.

\section{2.- El legislador y la ley.}

En primer lugar, se resalta la forma en que Bourdieu expresa, con claridad meridiana, cómo el magistrado, el juez, quien dicta sentencia, no es el único responsable de la aplicación del derecho, sino que lo es todo el conjunto de agentes que determinan e individualizan qué es delito y quienes los cometen; y así también, cómo dicha posición se hace extensible respecto al rol que ocupa el legislador, con respecto al grupo de agentes representantes de sus propios intereses. 
Se desnuda de esta forma, la representación oficial del mundo social perseguida por los grupos dominantes a fin de imponer su visión del mundo, favorable a sus propios intereses.

Así como el verdadero responsable de la aplicación del derecho no es tal o cual magistrado singular, sino todo el conjunto de agentes, a menudo en concurrencia, que proceden a la identificación y marca del delincuente y del delito; del mismo modo, el verdadero legislador no es el redactor de la ley sino el conjunto de los agentes que, determinados por los intereses y las sujeciones específicas asociadas a sus posiciones en campos diferentes (campo jurídico, pero también campo religioso, campo político, etc), elaboran aspiraciones o reivindicaciones privadas y oficiosas, las elevan al estado de "problemas sociales", y organizan las expresiones (artículos de prensa, obras, manifestaciones, peticiones, marchas, etc.) destinadas a "hacerlas avanzar". Todo este trabajo de construcción y formulación de las representaciones es lo que consagra el trabajo jurídico, añadiéndole el efecto de generalización y universalización que encierran la técnica jurídica y los medios de coerción que ella permite movilizar" 73

Quienes y qué intereses están detrás de la creación jurídica, da cuenta de un campo de acción especializado que es utilizado por los grupos dominantes como instrumento de normalización. El derecho en tanto discurso intrínsecamente poderoso y abastecido de medios físicos para hacerse respetar, está en condiciones de imponerse con el tiempo, del estado de creencia recta explícitamente enunciada como deber ser, al estado de adhesión inmediata a lo que cae por su propio peso, a lo normal, como cumplimiento de la norma que se suprime en cuanto tal en su propio cumplimiento.

Nuevamente el concepto de violencia simbólica ya expresado, nos permite comprender el manso sometimiento de las clases dominadas a voluntades ajenas a sus intereses y con ello el consenso y adhesión a normas jurídicas que no los representan, ni incluyen.

${ }^{73}$ Pierre Bourdieu , Ob cit 215 
La redacción y votación favorable de una norma legislativa, responde al conjunto de agentes que poseen el capital que les permite definir las modificaciones legislativas en base a sus propios intereses.

\section{3. - Sistemas antagónicos de acceso a la jubilación}

Si buscamos en la República Argentina, desde la recuperación del sistema democrático a la fecha, un núcleo legislativo que nos permita someter mediante su análisis y bajo la capacidad de percepción como observadores del mundo social circundante, las variables sometidas a proceso, encontraremos a las normas utilizadas para modificar abruptamente el sistema solidario de acceso a la jubilación en la Argentina, como un caso plausible de ser analizado en el presente

Nos preguntamos sobre qué agentes, representando qué intereses, lograron modificar un sistema de seguridad social inclusivo, precursor de la seguridad social en América Latina y que abarcaba masivamente al conjunto social, por un sistema de claro tinte liberal, individualista, y alejado del principio solidario de reparto.

En la Argentina de comienzos del siglo XX, cada actividad fue generando su propia protección social y fueron creados organismos administrativos, llamados "Cajas de jubilaciones o de previsión social", por lo que cada actividad se manejaba de manera autónoma y pagaba una jubilación diferente. Con la creación del Instituto Nacional de Previsión Social en 1944 se organizó el sistema previsional en forma similar a la conocida actualmente, hasta su positivización de forma clara, mediante la sanción de las leyes 18.037 y 18.038 que comprendían a todos los trabajadores en relación de dependencia tanto del ámbito público o privado y a los autónomos de cualquier actividad. El régimen de la leyes referidas respondía a un concepto de reparto, en el cual las nuevas generaciones aportaban con el fin de que los pasivos disfrutaran de un haber jubilatorio digno ${ }^{74}$.

Pero la tradición de casi un siglo de sistema jubilatorio de reparto, fue abruptamente truncada con la creación del Sistema Integrado de Jubilaciones y Pensiones mediante ley 24.241. Creándose así de forma integrada el sistema de régimen previsional público, cuya

\footnotetext{
${ }^{74}$ Grisolia Julio Armando, Tratado de Derecho del Trabajo y de la Seguridad Social TVI Abeledo Perrot, Bs. As. 2013, pag. 4698
} 
piedra angular era el otorgamiento de prestaciones por parte del Estado, financiadas por medio de un sistema de reparto asistido - que en la práctica no llego a ser siquiera un ingreso de subsistencia - y un régimen previsional basado en la capitalización individual que podía acumular cada trabajador en su periodo activo.

Se contraponen de esta forma, claramente dos sistemas antagónicos de acceso a la jubilación, uno centenario basado en los sólidos principios de la seguridad social, en el concepto de un estado de bienestar que procuraba una sociedad en clave igualitaria y por tal razón el sistema jubilatorio vigente tenía su sustento en el reparto de los aportes de los trabajadores activos, quienes financiaban de esta forma a los pasivos; y por otra parte, un sistema importado de otras experiencias basadas en el individualismo y la libertad de mercado (el caso chileno $)^{75}$, que tenía como piedra angular la capitalización y ahorro que podía realizar cada trabajador durante su periodo de actividad laboral, en beneficio propio y para ser percibido durante su periodo jubilatorio.

Si bien, en un claro proceso de revertir gran parte de las políticas económicas que imperaron durante los años en que el sistema de capitalización fue instaurado, el mismo fue derogado mediante ley 26.425 que dispuso la unificación en un único régimen previsional denominado Sistema Integrado Previsional Argentino, financiado a través de un sistema solidario de reparto y eliminándose así el régimen de capitalización imperante, lo cierto es que la instauración del régimen de capitalización a mediados de la década del 90', nos permite visualizar en un caso real, palpable y concreto, lo expresado en la presente.

La Argentina de comienzos de los años 90'tenia por objetivo terminar de construir los andamiajes del estado neoliberal que ya se había implementado mediante el genocidio del terrorismo de Estado a mediados de las década del 70' y en tal sentido la modificación de la estructura de seguridad social, propia de un sistema de Estado de Bienestar, se contraponía a ese objetivo.

"La experiencia fundamental del Estado neoliberal en la Argentina abarca el período de la dictadura (1976-1983) y bajo un gobierno constitucional, los años comprendidos entre fines de 1989 y la crisis final del 2001. Por lo tanto, la

\footnotetext{
75 Apreda Rodolfo, Administradoras de Fondo de Jubilaciones y Pensiones "Que son y como operan" Ediciones Macchi , Bs. As 1993
} 
formación del Estado neoliberal tuvo lugar en dos etapas dentro del cuarto de siglo comprendido entre 1976 y 2001; ambas abarcaron casi veinte años." ${ }^{.76}$

Presiones históricas del frente externo, realizadas por el Banco Mundial y el FMI, para abandonar el sistema de reparto ${ }^{77}$; aunado al beneficio pretendido por las cámaras empresariales al visualizar una baja en los aportes patronales y el gran negocio financiero que implicaba para Bancos y Compañías de Seguro la participación en el nuevo régimen de capitalización, todo ello de la mano de un gobierno de marcado y profundo tinte neoliberal y complaciente con las pretensiones de los grupos económicos, son sin lugar a dudas factores que determinaron la creación del sistema de AFJP.

Síntesis de lo expuesto, es el estudio realizado por el Ministerio de Empleo y Seguridad Social del Gobierno de España, sobre el sistema de jubilaciones en la Argentina:

No sólo se postergaba a los jubilados de entonces, también se hipotecaba el futuro: en 1994, con el apoyo del Banco Mundial y el FMI, el ministro de Economía Domingo Cavallo privatizó la cobertura previsional y dejó en mano de los bancos un descomunal negocio con los aportes patronales y de los trabajadores, manejando fondos por U\$S35.000 millones. Así, con comisiones de hasta el 30\% de los aportes previsionales, las AFJP (Administradoras de Fondos de Jubilaciones y Pensiones que fueron empresas privadas con fines de lucro, dedicadas a administrar los fondos generados con los aportes jubilatorios realizados por los trabajadores que optaran por ser incluidos en el régimen de capitalización individual establecido por la Ley 24.241 de reforma previsional del año 1993), embolsaron U\$S10.000 millones y al cabo de diez años, la cobertura previsional cayó un $10 \%{ }^{78}$

\footnotetext{
${ }^{76}$ La Construcción del Estado Neoliberal en la Argentina, Aldo Ferrer , Revista de Trabajo, Nueva Epoca, Año 8, Nro. 10, 2012

${ }^{77}$ Estabilización y Reforma Estructural en la Argentina (1989/1999) Julio C. Gambina http://biblioteca.clacso.edu.ar/ar/libros/sader/cap09.pdf

${ }^{78}$ http://www.empleo.gob.es/es/mundo/Revista/Revista175/29.pdf. Argentina: Jubilaciones
} 
Si bien es claro que el objeto de estudio no pasa por afianzarnos en un análisis de los motivos económicos del cambio de sistema, la introducción realizada nos permite analizar los motivos que influyeron en su realización.

Se puede entonces desmembrar con puntualidad la confrontación no sólo de dos sistemas de acceso a la jubilación, sino más grande aún, de dos sistemas económicos, sociales y culturales que se contraponen, donde el sistema jubilatorio cumplía un rol más (preponderante pero uno más) dentro de dicha confrontación.

Observamos entonces el fuerte surgimiento de un sistema económico liberal que se implementó bajo el genocida proceso de reorganización nacional y que luego de un pequeño declive durante mediados de la década del $80^{\prime}$, fue relanzado a comienzos de la década del 90' en el marco de un fuerte proceso privatizador y de desguace del Estado. Así, esa confrontación durante décadas entre un modelo de seguridad social inclusiva, implementado a partir de 1945 y el sistema de un Estado Liberal, se mantuvo a lo largo de los años lográndose implementar las políticas del libre mercado en su plenitud, durante la ola neoliberal.

Pensar a la reforma legislativa que llevó al cambio del sistema jubilatorio como una simple reforma legal, es precisamente olvidarse de los procesos de confrontación histórica existente durante décadas entre dos modelos económicos cuyo resultado, entre otros, es el cambio del sistema jubilatorio referido.

Las reformas introducidas en la segunda parte de la restauración neoliberal fueron más profundas.

"En ambas etapas, respecto de la estrategia puesta en práctica, se emplearon varios instrumentos semejantes pero, también, existieron importantes diferencias. Los semejantes incluyen la desregulación financiera y la apreciación del tipo de cambio. Las diferencias radican en las reformas del régimen jurídico institucional, terreno en el cual la segunda etapa avanzó con extraordinaria profundidad."79

La utilización una vez más del derecho como instrumento para regular y legitimar acciones que responden en su caso a relaciones de fuerza donde la clase dominante 
pretende instaurar su saber, se patentiza en la instrumentación de un sistema jubilatorio coherente con dichos intereses.

Así, la relativa autonomía que se confiere a la existencia de los problemas propios del sistema jubilatorio que pudieran influir en la reforma legislativa realizada (aumento de la población pasiva, disminución de los aportantes al sistema jubilatorio por crecimiento del trabajo sin registración, aumento de las prestaciones médicas requeridas), se encuentra visualizada al comprender el contexto económico y político en que la misma se produce.

La clara intención y presión del Banco Mundial, como también del Fondo Monetario Internacional, en fomentar la participación del capital privado en los sistemas jubilatorios para permitir la participación en sistemas de inversión, que se vio esparcido por todo el mundo y especialmente llevó a varios países de América Latina a reformar, durante un mismo período de tiempo, sus sistemas jubilatorios en pos de sistemas de capitalización $^{80}$; han sido sin lugar a dudas las relaciones de fuerzas que tensaron y provocaron el cambio de los sistemas existentes.

La disputa referida, amén de desarrollarse en el ámbito legislativo, también se desarrolló en el judicial mediante sendos fallos "Chocobar" (1996) y "Sanchez" (2005), por los cuales se demostró que las leyes en cuestión tuvieron asimismo su confrontación en el ámbito judicial.

En "Chocobar Sixto Celestino vs Anses" $" 1$, la C.S.J.N consideró constitucional la Ley de Convertibilidad ( 23.928) aplicada al caso en examen, es decir extendiendo la prohibición de indexación que la misma preveía a la movilidad jubilatoria prevista por el art. 14 bis de la Constitución Nacional y receptada por la aún vigente ley 18.037.

La mayoría entonces, si bien realiza una disquisición de la fecha de inicio en la aplicación de la prohibición de indexación, sí mantiene incólume el criterio de la inmovilidad del haber una vez modificado el sistema jubilatorio mediante ley 24.463. Dicha circunstancia recién será revertida con el fallo dictado en "Sanchez Maria del Carmen c/ Anses" 82 .

\footnotetext{
${ }^{80}$ Ferrante David, Danny Leipziger y PS Srinitivas, La Reforma de las pensiones en América Latina, www.imf.org/external/pubs/ft/fandd/spa/2002/09/pdf/ferranti.pdf

81 http://www.csjn.gov.ar/data/movilidad.pdf

${ }^{82}$ La Ley, Derecho del Trabajo 2005 A- 700
} 
La Corte estableció que la necesidad de mantener una proporción justa y razonable entre el haber de pasividad y la situación de los trabajadores activos, es propio del carácter integral que reconoce la Ley Suprema a todos los beneficio de la seguridad social. Reafirmando así, que la movilidad en los beneficios jubilatorios que nace de nuestra constitución, no puede ser limitada en su contenido mediante su vinculación con los recursos disponibles del estado.

Tal disparidad de criterios entre el precedente que considera a la Ley de Convertibilidad por sobre de la movilidad jubilatoria prevista en el régimen constitucional y el que pone las cosas en su justa apreciación constitucional en tanto la supremacía de ella por sobre la ley, da cuenta también de las relaciones que condicionan la autonomía del campo del derecho, expresadas esta vez hacia el adentro del Poder Judicial.

La creencia entonces de un orden jurídico autónomo ha sido utilizada en este caso puntual de análisis, para justificar la modificación de un sistema que se procuró presentar de forma aislada del contexto existente, como deficiente y obsoleto y de esta forma justificar por sí mismo su necesaria e imprescindible sustitución. Todo ello, mediante esa forma de legitimación por excelencia que es el derecho y que cuenta con el reconocimiento de los agentes involucrados.

\section{VII.- Conclusiones}

\section{1.- De la lucha política a la lucha por el derecho}

Paradójicamente, durante décadas hemos participado de la extenuante discusión sobre la fundamentación de los Derechos Humanos en cada una de sus distintas corrientes, 
a lo largo y lo ancho del sistema jurídico internacional. Ello, a pesar de que importantes filósofos del derecho se han expresado ya, hace tiempo, sobre la actual innecesaridad de la cuestión planteada $^{83}$, contrariamente a la necesidad sí, de fundamentar su protección y vigencia.

La discusión respecto a la fundamentación de los Derechos Humanos, ha acarreado el tiempo y las energías de gran parte de los doctrinarios y jurisconsultos dedicados a la interpretación y justificación del derecho. Curiosamente en dicha discusión, también acá, los Desc. fueron incluidos a título general, en la amplia gama de derechos que engloban los Derechos Humanos, sin distinción alguna, sin marcar sus importantes diferencias con los Derechos Civiles y Políticos en cuanto a las circunstancias de su creación. Todo ello cuando, como hemos visto, su exigibilidad y vigencia no gozaba de los mismos alcances que el resto de los Derechos Humanos reconocidos, lo cual amerita intentar encontrar siquiera una explicación al respecto.

El análisis sobre la fundamentación de los Derechos Humanos no escudriñó con detenimiento la influencia que el contexto histórico tuvo en su formulación para así entender su justificación. Ni siquiera lo expuesto fue resuelto por corrientes de fundamentación historicistas, que no llegan a analizar el rol que cumplió el nuevo sistema económico, político, social y cultural en las distintas corrientes legitimadoras de la vigencia de tales o cuales derechos.

Pero como decía Bobbio, nosotros estamos hablando hoy de la eficacia y vigencia de los Derechos Humanos, y particularmente en los Desc. Y es allí, donde el contrasentido referido aumenta exponencialmente, al darnos cuenta que es precisamente en el análisis de la génesis de los Desc, donde encontramos gran cantidad de respuestas sobre su situación actual. Discusión, que no se asienta sobre la fundamentación de los Derechos Humanos, pero que sí toma mayor relevancia que ella, al condicionar fuertemente la vigencia y exigibilidad de los mismos, antes y ahora.

Y ello no convierte a este plan de trabajo en un análisis sobre las teorías de justificación de los derechos humanos sino, lejos de ello, nos da las herramientas para comprender las causas originarias que nos colocan en la situación actual.

${ }^{83}$ Bobbio Norberto, El Tiempo de los Derechos Humanos, Ed. Sistema, Madrid 1991, pag. 61 
Hemos visto durante años, desarrollos doctrinales que hablan sobre la imposibilidad material que implica hacer exigibles a los Desc., su consideración de derechos programáticos, derechos promesa, expresiones de buena voluntad; sin comprender que su falta de fuerza no se explica por cuestiones de técnica jurídica en cuanto a su efectiva vigencia, sino que resultan propias de la relativa autonomía del campo del derecho, del poder de los agentes instituyentes del derecho y del mecanismo de violencia simbólica al que hiciéramos referencia antes de ahora.

Como resulta evidente, la construcción jurídica de las llamadas corrientes Operativas y Programáticas, no explica en definitiva los motivos de la propia existencia y creación de las mismas. Procuran sí, y lo logran, encasillar derechos en una y otra definición y a partir de allí enumerar cuáles derechos son posibles de reclamar su judicial cumplimiento y cuáles carecen del amparo del derecho para exigir su vigencia, pero con ello pasan por alto la explicación trascendental de las distintas condiciones que colocan a unos y otros en tal o cual encasillamiento. Así, ya se han referido y descartado los intentos por encuadrarlos en derechos de hacer y no hacer y, con ello, justificar una mera cuestión presupuestaria de parte del estado para explicar su validez.

Es por ello, que para poder explicar las aparentes contradicciones entre la vigencia y exigibilidad de unos y otros derechos, se reconoce la existencia de un universo social relativamente independiente en relación a las demandas externas, en cuyo interior se produce y se ejerce la autoridad jurídica. Entendiendo a su vez, a dicha autoridad jurídica, como la forma por excelencia de expresar la violencia simbólica monopolizada por el Estado.

Así, el discurso jurídico, en el caso puntual de la construcción de la exigibilidad y vigencia de unos derechos en desmedro de otros, no es ni más ni menos que el producto del funcionamiento del campo, cuya lógica está determinada por las relaciones de fuerza específica que le confiere su estructura y por la lógica interna de las obras jurídicas que delimitan el universo de soluciones posibles.

Lo expuesto se acredita cabalmente en el caso planteado en la presente.

Las modificaciones al régimen legal que enmarcaba el tipo de sistema jubilatorio vigente en la República Argentina, no fue modificado por cuestiones ajenas a las aquí planteadas. 
Así, la relativa autonomía del campo, se vio plasmada por las relaciones de fuerzas existentes hacia el afuera del campo jurídico y que determinaron la modificación de un sistema que tenía un siglo de raigambre en el país. Los agentes involucrados y de cuyos intereses se ha dado cuenta ut supra, son un clara demostración de las relaciones de fuerza especificas.

Comprobado ello es que se puede sostener que la positivización, la construcción en términos jurídicos, el traslado de las reclamaciones sociales al lenguaje de los derechos, en definitiva, el traslado de la lucha política por el cambio de un sistema capitalista a un nuevo terreno de discusión como es el campo jurídico, sometió la misma a las relaciones de fuerza propias del campo y con ello cambió radicalmente las reglas de discusión y las correlaciones de fuerza.

Sin lugar a dudas, las clases populares encuentran debilitada su correlación de fuerza en la discusión planteada hacia dentro del campo del derecho, que aquella investida en el marco de la disputa política.

Como se dijo, la percepción existente a comienzos del siglo pasado de que en el marco de limitar derechos (civiles y políticos) mediante otros derechos (sociales, económicos y culturales) se iba a obtener el respeto y vigencia de las reclamaciones que hasta ese momento se expresaban mediante la lucha política por el cambio del sistema político, económico y social, fue a tiempos vista, un error que no tuvo en consideración la relativa autonomía del campo jurídico y con ello, la correlación de fuerzas que existe con los agentes investidos de competencia social y técnica para decir lo que dice el derecho.

La domesticación de las movilizaciones populares, de las acciones de acción directa $\mathrm{y}$ de la confrontación en la calle y en las ideas, tuvo sin lugar a dudas resultados perjudiciales para el conjunto de los trabajadores.

De allí, resulta absolutamente predecible que luego de abandonada la lucha política, de ingresada la discusión al campo del derecho, aparezca el desarrollo de teorías del orden de los derechos operativos y programáticos, que responden ni más ni menos a los intereses de quienes ostentan el monopolio del derecho.

"A diferencia de la hermenéutica literaria o filosófica, la práctica teórica de interpretación de textos jurídicos no constituye un fin en sí misma, sino que, 
directamente orientada hacia fines prácticos y apta para determinar efectos prácticos, paga su eficacia con una restricción de su autonomía. “ 84

Lo que al comienzo pudo haberse percibido como un logro (el reconocimiento de los Desc.), rápidamente quedó inmerso en la inferioridad de condiciones para nominar el derecho referida; y por su parte, la fragilidad de los logros obtenidos quedó también demostrada con el sometimiento a unas construcciones jurídicas que, como se vio, los relegaban en su incidencia social y económica.

\section{2.- Génesis y exigibilidad}

Escudriñar el origen de los derechos humanos se presenta como una herramienta metodológica útil para intentar entender los motivos de semejante disparidad entre unos derechos y otros en cuanto a sus condiciones de vigencia.

Así, conforme fue descripto a lo largo de la presente, la aparición de los Derechos Humanos tal cual hoy los conocemos, tuvieron en la Revolución Francesa como objetivo primordial establecer las condiciones jurídicas y también ganar la batalla cultural, que permitiera asegurar la pujanza de un sistema económico, político y cultural, que tendrá su explosivo crecimiento y desarrollo con posterioridad, mediante la Revolución Industrial Inglesa.

Al decir de Hobsbawm, Francia aportó las ideas para que luego Inglaterra pudiera desarrollar las bases del sistema económico mundial de mediados del siglo XIX.

Si tales derechos entonces tenían como uno de sus principales fundamentos asegurar las bases del sistema económico que prácticamente ha hegemonizado la historia de la humanidad en los últimos 150 años, de ninguna forma los mismos podrían considerarse meras expresiones de buena voluntad, posibles de no ser reconocidas por el Estado.

El derecho había nacido para ser reconocido y apreciable de ser exigido su cumplimiento mediante el uso de la agencia judicial.

En palabras de uno de los máximos exponentes de dicha teoría jurídica, Kelsen, se puede decir que reconocido el derecho, existe la obligación jurídica de los individuos de comportarse de determinada manera frente a los otros individuos.

\footnotetext{
${ }^{84}$ Pierre Bourdieu, ob cit pag. 170
} 
Así, ocurre y fue establecido para los derechos creados con la finalidad de establecer las bases jurídicas del nuevo sistema político, económico, social y cultural que se estaba gestando.

Pero no pasó lo mismo con los Desc., es decir, se ha explicado cabalmente que dichos derechos han sido reconocidos como tales, en el marco de una nueva categoría jurídica que los pone en el lugar de ser respetados y garantizados sólo en la medida de las posibilidades presupuestarias del gobierno de turno. No gozaron así, de la obligatoriedad en su cumplimiento que caracterizó a los derechos humanos desde su surgimiento.

Es por ello que, también para el caso en estudio y recurriendo al proceso histórico en que los mismos se plasman en normas jurídicas y se construyen como derechos, se encuentra la explicación de su actual estado de exigibilidad y vigencia.

A diferencia de los derechos al libre tránsito, al libre comercio, a la inviolabilidad de la propiedad privada, la imposibilidad de la prisión por deudas, los derechos reconocidos a comienzos del Siglo XX, como el derecho al trabajo, a la seguridad social, a la vivienda digna, a la alimentación, no surgieron para sustentar las bases del sistema capitalista .

La génesis de los Desc. es bien distinta a la de los Derechos Civiles y Políticos.

Aparecen entonces como una forma de cambiar el terreno de la discusión, del ámbito político al campo del derecho, como mecanismo de resguardar y garantizar la vigencia y sostenimiento del sistema vigente, mantener en definitiva, el status quo .

El riesgo a la ruptura y quebrantamiento del orden establecido, motivó el reconocimiento de los Desc, en el ámbito de los derechos, como válvula de escape de las presiones sociales existentes en base a la injusta repartición de la riqueza impuesta por el sistema vigente. Mal podría entonces, si la aparición de los mismos fue al efecto de garantizar el sistema, reconocerlos en idénticas condiciones a los Derechos Civiles y Políticos que no haría otra cosa que obligar al Estado, pero sobre todo a las clases dominantes, a garantizar su cumplimiento y vigencia.

Así, para explicar las actuales condiciones de exigibilidad en lo que refiere a los Desc, es preciso remitirse al momento histórico de su conformación, a la comparación con el momento histórico de la aparición de los Derechos Civiles y Políticos y a la comprensión acabada que la situación de los mismos, en el marco de un universo social relativamente independiente, no escapa a las condicionalidades propia del campo del derecho. 


\section{Bibliografía}

- Abramovich Victor - Courtis Christian Los derechos sociales como derechos exigibles Ed. Trotta 2004.

- Abramovich, V. y Courtis, C., Los derechos sociales como derechos exigibles, cit., Cap. 1.; Hacia la exigibilidad de los derechos económicos, sociales y culturales. Estándares nternacionales y criterios de aplicación ante los tribunales locales", en Abregu, M, y Courtis, C., La aplicación de los tratados internacionales sobre derechos humanos por los tribunales locales, Ed. Del Puerto/CELS, Bs. As., 1997, pp. 283-350.

- Apreda Rodolfo, Administradoras de Fondo de Jubilaciones y Pensiones "Que son y cómo operan" Ediciones Macchi , Bs. As 1993 
- Atria Fernando, Existen Derechos Sociales XVI Jornadas Argentinas de Filosofia Jurídica y Social 24,25 y 26 de Octubre del 2006.

- Bourdieu Pierre, Intelectuales, Política y Poder, Ed. Eudeba 2006.

- Bourdieu Pierre, Poder, Derecho y Clases sociales Ed. Desclee de Brouwer SA 2001.

- Bonnewitz Patrice, La sociología de Pierre Bourdieu, Ed. Nueva Vision 2003.

- Cutrufelli Maria Rosa, La Ciudadana, Colección Umbriel Historica.

- Dworkin, Ronald, Los Derecho en Serio, Ed. Planeta Agostini

- Elster (1983) citado en "Las Teorías de la Justicia después de Rawls" Roberto Gargarella Pag. 103.

- Ferrante David, Danny Leipziger y PS Srinitivas, La Reforma de las pensiones en América Latina, www.imf.org/external/pubs/ft/fandd/spa/2002/09/pdf/ferranti.pdf.

- Ferrer Aldo, La Construcción del Estado Neoliberal en la Argentina, Revista de Trabajo, Nueva Epoca, Año 8, Nro. 10, 2012

- Gambina Julio C. "Estabilización y Reforma Estructural en la Argentina" (1989/1999) http://biblioteca.clacso.edu.ar/ar/libros/sader/cap09.pdf

- Grisolia Julio Armando, Tratado de Derecho del Trabajo y de la Seguridad Social TVI Abeledo Perrot, Bs. As. 2013,

- Guerin Daniel, "La lucha de clases en el apogeo de la revolución francesa" Biblioteca Militantes Ediciones, 2011.

- Hering, Rudolf von, “La lucha por el derecho”, ILSA, Bogotá, 2004.

- Hernandez Sampieri Roberto, Metodología de la investigación, 4ta. Edición 2006.

- Hobsbawm Eric, La Era de la Revolución 1789-1848, Critica, 2010.

- Hunt, Lynn, La Invención de los Derechos Humanos, Tiempo de Memoria Tus Quets Editories, 2010,

- Kelsen Hans, Teoría Pura del Derecho, Ed. Universidad Autónoma de México 1979.

- Lamaitre, Julieta, Fetichismo Legal Derecho, violencia y movimientos sociales en Colombia, Universidad de los Andes, Bogotá Sela 2007.

- Lasalle Ferdinand ¿Qué es una Constitución? Dialogo Abierto Mexico 1996.

- Lillio Jose Luis, Psicoanalisis y Marxismo, http://www.temasdepsicoanalisis.org/

- Marconi Alicia, artículo “La deuda Interna” Diario Página 12. Suplemento Futuro. 27/03/2004.

- Mark Tushenet en Roemer Andres Introducción al Análisis Económico del Derecho México Fondo de Cultura Económica 1994.

- Marx Carlos y Engels Federico, Manifiesto Comunista, Ed. Nuestra América 2004.

- Marx Carlos El Capital Tomos I, II y III Siglo XIX Editores.

- Marx Carlos, Sobre La Cuestión Judía Ciencias Sociales Prometeo 2004 pag. 31 y Critica del Programa de Gotha, Ateneo Buenos Aires 1973.

- Ministerio de Empleo y Seguridad Social del Gobierno de España http://www.empleo.gob.es/es/mundo/Revista/Revista175/29.pdf.Argentina: jubilaciones

- Nietzsche Friedrich Genealogía de la Moral Cap. I: 4 y 5

- Ruiz Alicia E. “Aspectos Ideológicos del Discurso Jurídico” en Materiales para una Teoría Crítica del Derecho Lexis Nexis Abeledo - Perrot 2006. 
- Sazbon, Jose "Seis estudios sobre la revolución francesa" Ediciones al Margen, 2005.

- Scheldon, Arthur y FG. Pennance, Diccionario de Economía, Orbis, Barcelona, 1983.

- Schleifer Pablo, Campo científico, ciencia y uso político de la ciencia en el pensamiento de Bourdieu El sentido práctico. Buenos Aires. Siglo XXI Editores, Revista de la Facultad 14, 2008.

- Torres, José María, Los Derechos del Hombre, Editorial Universitaria de Buenos Aires 1989

- Walsh Rodolfo, El Cordobazo "Periódico de la CGT de los Argentinos" Mayo de 1968 .

- Wlasic Juan Carlos Manual Critico de Derechos Humanos 2da. Edición Actualizada y Ampliada, La Ley 2011.

\section{Fallos, Tratados, Informes y Observaciones Generales}

- Badaro Adolfo Valentín c/ Anses s/ Reajustes varios"-B.675.XLI-08-08-2006

- Chocobar Sixto Celestino vs. Anses. www.csjn.gov.ar/data/movilidad.pdf

- Comité de Derechos Económicos, Sociales y Culturales. E/C.12/1/Add. 38, 8 de diciembre de 1999.

- Comité de Derechos económicos, sociales y culturales. Observación General N 12 . $20^{\circ}$ Período de Sesiones. 1999.

- Comité de derechos económicos, sociales y culturales. Observación General N4. Sexto Período de Sesiones. 1991. HRI/GEN/1/Rev. 7.-

- Declaración de Derechos y Deberes del Hombre y del Ciudadano, 1789.

- Edmedkjian c/ Sofovich-1992 CSJN.

- Giroldi Horacio s / Recurso de Casación. C.S.J.N 1995 www.lanuevoderecho.com.ar/Recursos/Fallosoa.htm

- Informe presentado ante la Comisión de Derechos Humanos del Consejo Económico y Social de las Naciones Unidas durante su 61 Período de Sesiones. 25 de Febrero de 2005. E/CN.4/2005/43.

- Informe presentado ante la Comisión de Derechos Humanos del Consejo Económico y Social de las Naciones Unidas durante su $61^{\circ}$ Período de Sesiones. 3 de Marzo de 2005. E/CN.4/2005/48.

- Gobierno de la Ciudad de Buenos Aires, Comisión Municipal de la Vivienda, Gerencia de Promoción Social Urbana, Datos poblacionales, Composición Demográfica de las Villas, 1999. La información recogida por el Gobierno de la Ciudad arroja como constante que el número de familias que habita cada villa supera ampliamente la cantidad de viviendas existentes.

- Informe presentado ante la Comisión de Derechos Humanos del Consejo Económico y Social de las Naciones Unidas durante su 61 ${ }^{\circ}$ Período de Sesiones. 25 de Febrero de 2005. E/CN.4/2005/43. 
- Informe presentado ante la Comisión de Derechos Humanos del Concejo Económico y Social de las Naciones Unidas, Doc.E/C.12/1994/20 at.52 (1995), punto 237.

- Presentación ante el Comité de Derechos Económicos, Sociales y Culturales. Cuestiones a considerar en la evaluación del Segundo Informe de Argentina en cumplimiento de los Artículos 16 y 17 Del Pacto. La elaboración de este documento ha sido coordinada por el Centro De Estudios Legales Y Sociales (Cels) con la colaboración del Servicio Paz y Justicia (Serpaj) y ha contado con la adhesión de numerosas entidades intermedias de nuestro país.

- Sanchez Maria del Carmen vs. Anses. La Ley, Derecho del Trabajo 2005 A- 700 